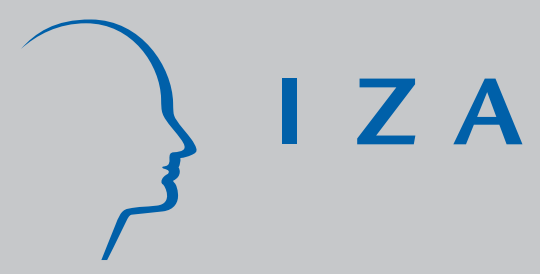

IZA DP No. 1767

Executive Compensation, Firm Performance, and Corporate Governance in China: Evidence from Firms Listed in the Shanghai and Shenzhen Stock Exchanges

Takao Kato

Cheryl Long

September 2005 


\title{
Executive Compensation, Firm Performance, and Corporate Governance in China: Evidence from Firms Listed in the Shanghai and Shenzhen Stock Exchanges
}

\author{
Takao Kato \\ Colgate University, Columbia University \\ and IZA Bonn \\ Cheryl Long \\ Colgate University, Stanford University \\ and University of Electronic Science and Technology of China \\ Discussion Paper No. 1767 \\ September 2005 \\ IZA \\ P.O. Box 7240 \\ 53072 Bonn \\ Germany \\ Phone: +49-228-3894-0 \\ Fax: +49-228-3894-180 \\ Email: iza@iza.org
}

\begin{abstract}
Any opinions expressed here are those of the author(s) and not those of the institute. Research disseminated by IZA may include views on policy, but the institute itself takes no institutional policy positions.
\end{abstract}

The Institute for the Study of Labor (IZA) in Bonn is a local and virtual international research center and a place of communication between science, politics and business. IZA is an independent nonprofit company supported by Deutsche Post World Net. The center is associated with the University of Bonn and offers a stimulating research environment through its research networks, research support, and visitors and doctoral programs. IZA engages in (i) original and internationally competitive research in all fields of labor economics, (ii) development of policy concepts, and (iii) dissemination of research results and concepts to the interested public.

IZA Discussion Papers often represent preliminary work and are circulated to encourage discussion. Citation of such a paper should account for its provisional character. A revised version may be available directly from the author. 


\section{ABSTRACT}

\section{Executive Compensation, Firm Performance, and Corporate Governance in China: Evidence from Firms Listed in the Shanghai and Shenzhen Stock Exchanges*}

This paper provides evidence on how executive compensation relates to firm performance in listed firms in China. Using comprehensive financial and accounting data on China's listed firms from 1998 to 2002, augmented by unique data on executive compensation and ownership structure, we find for the first time statistically significant sensitivities and elasticities of annual cash compensation (salary and bonus) for top executives with respect to shareholder value in China. In addition, sales growth is shown to be significantly linked to executive compensation and that Chinese executives are penalized for making negative profit although they are neither penalized for declining profit nor rewarded for rising profit insofar as it is positive. Perhaps more importantly, we find that ownership structure of China's listed firms has important effects on pay-performance link in these firms. Specifically state ownership of China's listed firms is weakening pay-performance link for top managers and thus possibly making China's listed firms less effective in solving the agency problem. As such, ownership restructuring may be needed for China to successfully transform its SOEs to efficient modernized corporations and reform its overall economy.

JEL Classification: $\quad$ M52, M12, J33, P31, P34, O16, G30, O53, G15

Keywords: executive compensation, firm performance, corporate governance, ownership structure, China, and transition economies

Corresponding author:

Takao Kato

Department of Economics

Colgate University

13 Oak Drive

Hamilton, NY 13346

USA

Email: tkato@mail.colgate.edu

\footnotetext{
* This research was funded by grants from the ABDI (Asian Development Bank Institute) and the Asian Studies program of Colgate University, as well as a Picker Research Fellowship from the Research Council of Colgate University. Kevin J. Murphy, Runtian Jing, and Jan Svejnar provided us with advice and encouragement on our research program on executive compensation in China in general. The paper also benefited from comments and suggestions from participants at the Public Economic Theory Annual Meeting 2004 (Beijing), at the Economic Department seminar in Wesleyan University, and at the ASSA meetings in Philadelphia in January 2005. The data used in the paper are provided by Shenzhen GuoTaiAn IT Co. and SinoFin Inc. We are grateful for support from these individuals and organizations.
} 


\section{Introduction}

Executive compensation has attracted much attention from economists in the past two decades yet most academic work on executive compensation has been concentrated on a few developed countries such as the U.S. and the U.K., mainly due to data availability. ${ }^{1}$ In light of the mounting interest in the vital role that corporate governance may play in economic development, however, it is of considerable importance to study how firms in developing countries compensate their top executives. ${ }^{2}$ In particular, for transition economies struggling to transform their state-owned enterprises (SOEs) into profitable modern firms through various reform measures, the provision of efficient managerial incentives is a crucial ingredient of the successful transition of the economy. ${ }^{3}$ Since executive pay-performance link represents the bulk of managerial incentives for top management, a closer look at the nature of pay-performance link for top management in transitional economies will provide much needed information for the evaluation of the current reform effort and the designing of future reform measures.

Aided by two newly available data sets, in this paper we study the nature of pay-performance link for top management in a group of firms from the largest transition economy in the world, China. These are firms listed in China's two thriving stock exchanges, the Shanghai Stock Exchange and the Shenzhen Stock Exchange. On the one hand, since firms aspiring to become listed are required to go through corporate restructuring according to the western-styled Corporate Law of 1993 and listed firms are under increasing pressure to adopt certain good corporate structure practices (such as the inclusion of independent directors in the board and the separation of the board chairmanship and the CEO position),

\footnotetext{
${ }^{1}$ See, for example, Murphy (1999) for an excellent survey of the largely empirical literature on top management incentives; and Gibbons (1997) for the mostly theoretical literature. For an authoritative survey of earlier work, see Rosen (1990) who concludes his survey by urging scholars to broaden their inquiry beyond the U.S. to other countries. For an excellent survey of the corporate governance literature in general, see for instance Shleifer and Vishny (1997).

${ }^{2}$ Bai et al. (2004) finds evidence that listed firms in China with better corporate governance measures are associated with higher stock market valuation. Furthermore, the premiums related to better corporate governance are found to be substantially higher than those in other emerging markets in the world. Corporate governance appears to matter in China. For similar studies on other developing and transitional economies, see, for instance, Black (2001), Klapper and Love (2002), and Black, Hasung and Kim (2003).

${ }^{3}$ Aghion, Blanchard, and Burgess (1994) stress the importance of managerial incentive reform in the successful economic transition of former socialist economies.
} 
the process of getting listed has the potential of enhancing the quality of corporate governance in these firms. This may explain why getting listed on the stock market has been trumpeted as a major vehicle for China's SOE reform in recent years.

On the other hand, although privately controlled firms have gradually increased their presence, the majority of listed firms on the Chinese stock market are still controlled by the government. In other words, the ownership structure of most listed firms in China is still dominated by government shares, which casts doubt on the effectiveness of the corporate restructuring process (or GongSi GaiZhi in Chinese). In order to draw some conclusions about China's success in her use of stock market listing as a vehicle for SOE reform, we explore how these firms relate their executive compensation to their firm performance and how such relationships are influenced by their ownership structure.

Specifically, we begin with estimating two standard measures of pay-performance relations for executives (see, for example, Murphy, 1999). First, we estimate the sensitivity of pay with respect to shareholder value by regressing the change in executive compensation on the change in shareholder value of the firm. Second, we estimate the elasticity of pay with respect to shareholder value by regressing the change in the log of executive compensation on the change in the log of shareholder value of the firm. ${ }^{4}$ That is,

$$
\Delta \mathrm{Y}_{\mathrm{it}}=\mathrm{a}+\mathrm{b} \Delta \mathrm{V}_{\mathrm{it}}+\mathrm{u}_{\mathrm{it}}
$$$$
\Delta \ln Y_{i t}=\alpha+\beta \ln \left(1+R_{i t}\right)+u_{i t}
$$

where $\mathrm{Y}_{\mathrm{it}}$ is executive compensation of firm $\mathrm{i}$ in year $\mathrm{t}$; $\mathrm{V}_{\text {it }}$ is shareholder value of firm $\mathrm{i}$ in year $\mathrm{t}$; and $\mathrm{R}_{\mathrm{it}}$ is stock return of firm i in year t. We control for time-specific shocks that are common to all firms by including year effects in our regressions. For the disturbance term, $\mathrm{u}_{\mathrm{it}}$, we assume $\mathrm{u}_{\mathrm{it}} \sim \mathrm{NID}\left(0, \sigma^{2}\right)$.

In addition to stock performance, we also study the relationship between executive compensation and the accounting performance of the firms. Following the literature, we estimate the semi-elasticity of pay with respect to stock rate of return, sales growth, change in pre-tax income, and the negativity of pre-

\footnotetext{
${ }^{4}$ As shown in Murphy (1999), the change in the log of shareholder value of the firm is equal to $\ln \left(1+R_{i t}\right)$ where $R_{i t}$ is stock return of firm $i$ in year $t$.
} 
tax income, by regressing the change in the log of executive compensation on $R_{i t}, S_{i t}$ (sales growth of firm $\mathrm{i}$ in year $\mathrm{t}$ ), $\Delta \mathrm{P}_{\text {it }}$ (the change pre-tax income), and $N$, a dummy variable indicating that the firm's pre-tax income is negative.

We will then augment these standard executive compensation equations by a variable indicating the degree to which the firm is owned and controlled by the state and an interaction term involving such a state ownership variable and firm performance. Various robustness tests of the estimates will be further conducted.

In short, we find statistically significant sensitivities and elasticities of annual cash compensation (salary and bonus) for top executives with respect to shareholder value in China's listed firms. The size of the estimated sensitivities imply that a 1000 RMB increase in shareholder value yields a 0.053 RMB increase in annual cash compensation, whereas the size of the estimated elasticities suggest that a 10 percent increase in shareholder value results in 3.6 percent increase in annual cash compensation for top executives. We also find that sales growth is significantly linked to executive compensation and that Chinese executives are penalized for making negative profit although they are neither penalized for declining profit nor rewarded for rising profit insofar as it is positive.

Perhaps more importantly, the strength of the link between compensation and performance varies across firms with different ownership structure. Our findings suggest that private ownership and control of listed firms in China enhance the link between firm performance and executive compensation, while government ownership weakens executive pay-performance link and thus makes the firms less effective in solving the agency problem between their shareholders and management.

These results suggest that the interests of top executives in firms that are less state-controlled are more in line with those of the shareholders and thus these companies operate more like firms in the West. This is consistent with the belief that the piecemeal enterprise reform measures adopted in China will need to be supplemented by changes in ownership structure in order to ensure the successful 
transformation of SOEs into profitable modern corporations. ${ }^{5}$ As such, China may be in great need for ownership restructuring to fully succeed in transforming its SOEs to efficient modernized corporations, in the direction of converting state shares to public shares (shares owned by private individuals or private firms including foreign investors).

Finally, to our knowledge, this paper is the first to look at pay-performance sensitivities and elasticities for listed firms in China. Systematic research outside the U.S. on executive compensation is still in its infancy, especially in emerging markets, mostly due to the limited data availability. Our study contributes to the literature on executive compensation in emerging markets. ${ }^{6}$ Specifically, previous studies on pay-performance linkage in China focused on SOEs before the stock market era and found positive and significant link of accounting performance measures to executive compensation (Groves et al., 1995, and Mengistae and Xu, 2004). ${ }^{7}$ In addition, they demonstrated that most SOE reform measures in the 1980s and the 1990s were by and large successful in enhancing pay-performance link. Thus, Groves et al. (1995) provide evidence consistent with the view that the SOE reform measures in the 1980s including profit responsibility contracts have improved pay-performance linkage. Mengistae and Xu (2004) show that certain specific reform measures such as profit retention increase pay-performance link while others including autonomy in production and sales decisions do not.

By exploring pay-performance relations for listed firms in China, our paper complements these early pre-stock market studies. First, by using unique data on executive compensation in China’s listed firms, we are able to provide the first estimates on pay-performance sensitivities and elasticities (standard

\footnotetext{
${ }^{5}$ For the inefficacy of China's piecemeal approach to economic reform, see for example Lardy (1998). For specific studies suggesting the importance of ownership structure in China, see, for instance, Chang, McCall, and Wang (2003), who find that Chinese township and village enterprises with better defined ownership have significantly better performance. In addition, Zhang, Zhang, and Zhao (2003) find that state ownership leads to lower R\&D and productive efficiency in industrial firms.

${ }^{6}$ For a literature review of prior studies on U.S. CEO compensation, see Footnote 1. The U.K. is one other country where CEO compensation data are readily available (Conyon, 1997). For other countries, in particular Asian countries, data on CEO compensation are typically not publicly available and thus most studies use average pay for all executives. See, for instance, Kaplan (1994), Xu (1997), Ang and Constand (1997), Joh (1999) and Kubo (2001) on Japan; and Kato, Kim and Lee (2004) on Korea. The rare exception is Kato and Kubo (2005), which use proprietary data on Japanese CEO compensation.

${ }^{7}$ Liu and Otsuka (2004) provide useful information and findings on top management incentives in steel industry in four provinces in China although they do not examine pay-performance sensitivity.
} 
measures of pay-performance relations used in the literature gauging the degree of sensitivities of executive pay to stock market performance as opposed to accounting performance). Second, while the majority of listed firms are still controlled by the government, there is a considerable variation in the degree of state ownership and control among listed firms. Such a variation allows us for the first time to study how ownership structure influences pay-performance relations and thus the quality of corporate governance.

The structure of the paper is as follows. In Section II, we provide relevant institutional information on China's stock market, listed firms, and executive compensation in the context of its enterprise reform, while reviewing the relevant literature. Section III describes data, followed by Sections IV, where the main results are presented. Section V concludes by summarizing the findings and discussing their policy implications.

\section{$\underline{\text { II. Background institutional information }}{ }^{8}$}

\section{Emerging Stock Market and Listed Firms in China}

We begin with a brief description of the emergence of China's stock market and its listed firms.

In China the interest in the stock market and listing of firms on the market was initially sparked in the late 1980s and early 1990s as part of the government's effort to help SOEs raise capital and reduce debt burden. In recent years, however, the development of China’s stock market has taken on additional significance, given that the public listing of firms has been heralded as a centerpiece of China's enterprise reform, especially for its largest SOEs. ${ }^{9}$

\footnotetext{
${ }^{8}$ This section is enriched especially by a series of interviews we conducted with executives of listed firms and securities firms, staff of government regulatory agencies, and researchers studying corporate governance issues in four Chinese cities, Chengdu (Sichuan), Shanghai, Beijing, and Tianjin, during the summer of 2004. We are grateful for support from these individuals.

${ }^{9}$ The government's policy stance to emphasize the role of the stock market and the listed firms in China's SOE reform can be observed from numerous speeches given by policy makers in charge of enterprise reform. For instance, in a speech given at the "Meeting on How to Establish the Modern Enterprise System in Listed Firms" held in December of 2002, the chairman of the Economic and Trade Commission, Mr. Rongrong Li, stated that China's enterprise reform and modernization in the coming years will be focused on listed firms.
} 
The Shanghai Stock Exchanges was established at the end of 1990 and shortly after that, the Shenzhen Stock Exchange started operating in early 1991 and the first Chinese company went public in 1991. But the rapid development of China’s stock market did not begin until the mandate of the Chinese Communist Party's (the CCP) $14^{\text {th }}$ Congress. In contrast to the largely piece-meal SOE reform measures adopted in the 1970s and 1980s, the CCP's $14^{\text {th }}$ Congress in October 1992 opened a new chapter in China's SOE reform by proposing to establish a modern corporation system that resembles the West. ${ }^{10}$ This decision was made possible only after the Party accepted to "build a market economy with Chinese characteristics” as a target for China's economic reform and has made SOE reform a major component of China’s economic reform since then.

Soon after the $14^{\text {th }}$ Congress, the National Peoples' Congress (NPC) and its Standing Committee passed the Corporate Law in 1993, which laid out the fundamental rules for corporate governance in modern Chinese corporations and provided blueprints for SOE restructuring and reform. In 1997, the Chinese Communist Party’s 15th Party Congress made the shareholding system a centerpiece of China's enterprise restructuring and public listing a main vehicle to achieve the goal for large SOEs, and this led to a rapid increase in the number of firms listed in the two stock exchanges in China. ${ }^{11}$ The development of the stock market was further prompted by the passage of the Securities Law in 1998. By early 2004, China's stock market has emerged as the eighth largest in the world with close to 1,300 listed firms and market capitalization of over $\$ 550$ billions. $^{12}$

The 1993 Corporate Law of China recognizes two types of corporations: closely held

\footnotetext{
${ }^{10}$ Earlier SOE reform measures were mainly designed to align the interests of SOE management and the government, and they include the administrative decentralization and profit retention policies (fangquan rangli) in the late 1970s to the early 1980s; the changes in the forms of profit sharing and funding sources for SOEs during the mid to late 1980s (ligaishui and bogaidai); and the incentive contracts for managers and workers during the late 1980s (chengbaozhi). For a detailed discussion on China's earlier enterprise reform from a historic perspective, see Naughton (1995) and Yang (1997). For a general discussion on enterprise reform in transition economies, see Megginson and Netter (2001).

${ }^{11}$ See, for instance, Jefferson et. al. (2003).

12 There were 1,288 firms listed in the Shanghai and Shenzhen Stock Exchanges by the end of April in 2004. Source: Shanghai and Shenzhen Stock Exchanges. One estimate puts the market capitalization in China's stock markets at about 50\% of China's GDP, which is comparable to the ratio in Japan (See People's Daily, Feb. 22, 2001). A more conservative estimate discounting values of shares owned by the state and legal persons puts the ratio at $20 \%$.
} 
corporations (youxian zeren gongsi) and publicly-held corporations (gufen youxian gongsi), with the latter requiring higher levels of registered capital and a larger number of shareholders. Both types of corporations are required to establish three corporate governing bodies: (i) the shareholders (acting as a body at the shareholder general meeting); (ii) the board of directors; (iii) and the board of supervisors, although a closely held corporation with "few shareholders” and "small capital size” can take exceptions to the rules. ${ }^{13}$

In terms of property rights created by share ownership, the Corporate Law clearly stipulates that shareholder rights include the right to investment interests, the right to make decisions regarding corporations’ development strategies, and the right to hire management (Corporate Law §1, 1993).

Although the final source of power in the corporation rests with the shareholder general meeting, the general meeting delegates to the board of directors the rights to make daily operation decisions including hiring and firing the management and determining the compensation of the management, while the board of supervisors in Chinese firms consists of both shareholder representatives and company employee representatives and oversees the board of directors and management (Corporate Law §3, 1993).

Listed firms are publicly-held corporations that are allowed by the Chinese Securities Regulatory Commission (CSRC) to issue and trade shares in one of the two stock exchanges in China, the Shanghai Stock Exchange and the Shenzhen Stock Exchange. As such, in addition to abiding by the stipulations in the Corporate Law, listed firms are regulated by the Securities Law of 1998 and other stipulations issued by the CSRC. In particular, the CSRC has various disclosure requirements for listed firm in China, including publication of its annual report in at least two newspapers with large circulations approved by the commission, in which basic information of the firm's ownership structure, investment decisions, and financial conditions is disclosed. The firm is also required to provide several measures of executive compensation in its annual report, which makes this study possible.

\footnotetext{
${ }^{13}$ Specifically, a small closely held corporation can opt to not set up a board of directors. Instead it suffices to have a single executive director and the executive director may serve concurrently as the manager. In addition, such a corporation is not required to have an entire board of supervisors. One or two supervisors will suffice. See Corporate Law §3 (1993). For a detailed discussion on China’s Corporate Law of 1993, see Schipani and Liu (2001).
} 
Although on the surface the corporate structure of listed firms in China looks very much like listed firms in the West, ownership structure of these firms is very different from that in the U.S. and other market economies, with the most important feature being the dominance of government ownership. Most listed firms are restructured from SOEs, and when going public, state owned assets in these firms are converted into shares owned directly or indirectly by the government and in addition they are encouraged to issue new shares to other SOEs. As a result, the government dominates the ownership and control of many listed firms in China. ${ }^{14}$

\section{Executive Compensation Reform in China}

We now describe how the mechanism for determining executive compensation in Chinese firms, especially Chinese SOEs, has evolved in the past two decades, with particular focus on the current form of executive compensation reform in China, the "yearly salary system.” Before economic reform started in the late 1970s, executive compensation, as part of the rigid compensation system employed in prereform Chinese enterprises, was largely determined based on factors that do not reflect either firm performance or individual contributions. And the factors include the region, industry, level of management (by central or local government) and size of the enterprise, and job title, occupation, and seniority of the individual. The profit retention policies introduced in the late 1970s and the "profit responsibility contract” system adopted in the 1980s represented the early steps in China’s executive compensation reform, where managers were allowed to use a portion of the residual profit to increase compensation for workers and themselves. ${ }^{15}$

Two waves of SOE compensation reforms promulgated in 1985 and 1992 allowed the SOE's wage budget to be linked to its economic performance and permitted the SOE to set its own internal wage structure within the wage budget, thus helped introduce more profit-oriented incentives to employees working for SOEs in general. One main compensation mechanism that emerged from this reform is the

\footnotetext{
${ }^{14}$ See for instance Sun and Tong (2003) and Bai, et. al.(2004).

${ }^{15}$ See Groves et al. (1995) and Mengistae and Xu (2004) for empirical evidence that executive compensation was linked to accounting performance measures under the "profit responsibility contract" system.
} 
system of fixed monthly salary plus bonus payment for SOE employees. Two constraints, however, limited the scope of reform in executive compensation. The wage budget for SOEs still had to be approved in advance by the former Ministry of Labor (MOL) to avoid paying a Wage Adjustment Tax for the part exceeding the governmental standard wage bill. In addition, management in an SOE still did not have the ability to effectively hire and fire employees. As a result, the bonus payment in this system is largely egalitarian compensation that lacked real incentive effects (Liu and Otsuka, 2004). ${ }^{16}$

It was only after the pilot implementation of the "yearly salary system” in 1992 that substantive executive compensation reform really started to take off in Chinese SOEs. In the same year when the CCP accepted “a market economy with Chinese characteristics” as the target for China’s economic reform and a modern corporation system resembling corporations in the West as the goal for SOE reform, the State Council approved the Shanghai Hero Pen Company to try out the pilot “yearly salary system” for its top executives. By 1994, Beijing, Shenzhen, Sichuan, Henan, and Liaoning had also started their own pilot programs, followed by the national pilot program implemented in 100 large SOEs throughout the country. The pilot experiment was well received and the "yearly salary system" thus became the most important form of executive compensation reform in China since 1997, when the former MOL officially advocated "vigorous and smooth implementation" of the system in SOEs. ${ }^{17}$

The compensation for top executives in the "yearly salary system" consists of two parts: a fixed component (known as the base salary) that depends on both the average wage for ordinary employees and the size of the enterprise; and a variable component (known as the risk salary) that is linked to both the base salary and the performance of the firm in the year. The base salary is paid to executives on a monthly basis, while the risk salary (or at least a large part of it) is distributed at the end of the year. ${ }^{18}$

\footnotetext{
${ }^{16}$ For a detailed discussion on general compensation reforms in China, see Yueh (2004).

${ }^{17}$ See the former MOL circular "The Main Goals and Policy Measures for Enterprise Compensation Reform during the Ninth Five Year Plan Period” issued in March of 1997.

${ }^{18}$ The discussion on the "yearly salary system" benefited greatly from the actual compensation plans provided by two firms in Sichuan as well as our interviews with Chinese executives in the summer of 2004 in Beijing, Shanghai, and Sichuan Province. . For an authoritative discussion on the various components of CEO pay in the U.S., see Murphy (1999).
} 
In other words, the pay-performance structure of the variable component in the "yearly salary system" is much like "bonus" in the compensation package of a CEO working for a western firm. The “yearly salary system” thus corresponds to a typical cash compensation package in western firms.

Therefore, in advocating such a system, China's current public policy makers appear to recognize the importance of executive compensation as a key incentive mechanism for top management and consider it a vital component of enterprise reform. Being harbingers of the new modern Chinese enterprises, we expect the listed firms to have been among the first to adopt such a system with the implied strong payperformance link for top managers.

However, despite of being conceived first as a way to improve SOE performance, some evidence suggests that state ownership hinders the effective adoption of the "yearly salary system” in two ways. First of all, privately controlled listed firms seem to be quicker in adopting the yearly salary system than their state-controlled counterparts. ${ }^{19}$ In addition, while private firms typically include profit, sales growth, and other accounting indicators as performance measures when calculating executive risk salary, state controlled firms are more likely to include growth rate of state owned assets and non-financial measures into executives’ performance evaluation, thus reducing the weights assigned to accounting measures. For example, some SOEs such as public utilities consider non-financial measures such as occupational safety and health records. ${ }^{20}$

\section{Corporate Governance in Chinese Listed Firms}

Both pessimism and optimism have been expressed about the efficacy of China's enterprise reform via the public listing its SOEs without substantial privatization. The pessimistic view emphasizes the fact that the majority of listed firms are still owned and controlled by the state, and in the absence of

\footnotetext{
${ }^{19}$ See "Report on Chinese Entrepreneurs: Emergence and Development”(Zhongguo qiyejia chengzhang yu fazhan baogao), p27, issued by the Survey System for Chinese Entrepreneurs 2004.

${ }^{20}$ It would be useful to study directly how the adoption of the system and the various weights assigned to different measures affect the performance-compensation relationship. Unfortunately, for the listed firms in our sample, we do not have data either on the adoption of the "yearly salary system" or on the use of specific firm performance measures in the "yearly salary system."
} 
wholesale privatization of listed firms, the transformation of SOEs to modern and efficient corporations is still very limited even if they are stock-exchange listed. For instance, Lin (2001) argues that China's SOE restructuring has failed to facilitate any major improvement in corporate governance. Based on interviews with government officials, stock exchange regulators, CPAs, security and corporate lawyers, and officials at both listed and non-listed firms, Lin (2001) concludes that corporate governance in listed firms in China is of very low quality, characterized by excessive powers of the CEO and insider control, inadequate safeguards for outsiders, weak managerial incentives, and inadequate transparency and disclosure. According to Lin (2001), the source of poor corporate governance practices in Chinese-listed firms is the large percentage of company shares owned by the state, which leads to the government's dominant role in firm management and control. In short, many listed firms are viewed as merely the reincarnations of SOEs that have inherited both the inferior corporate governance and the poor firm performance. $^{21}$

More generally, there are two reasons why listed firms with greater state ownership and control behave differently from more privatized listed firms. First, because state shares are not tradable on the market, greater state influence means less exposure to the market and thus less market discipline on executives and more room for rent-seeking behavior, resulting in poorer corporate governance and weaker pay-performance link for top management. Second, listed firms with greater state ownership and control are more likely to remain under the influence of the legacy of arrangements in old Socialist economies and less quick to adopt new practices. ${ }^{22}$ For instance, although the "yearly salary system” was first advocated by the government as a mechanism to improve SOE performance, the new compensation system saw much faster adoption among privatized firms than among SOEs after it proved to be an effective incentive mechanism. According to a national survey conducted in 2002, the percentages of enterprises that had adopted this more progressive compensation system ranged from $15.2 \%$ for SOEs, to

\footnotetext{
${ }^{21}$ For a similar view, see Schipani and Liu (2001).

${ }^{22}$ For the negative impact on managerial incentives of these arrangements, see Bonin (1976), Weitzman (1976), Kornai (1992), Ickes and Samuelson (1987), Litwack (1991), and Dewatripont and Roland (1997).
} 
20.2\% for collective firms and $41.4 \%$ for privatized firms. ${ }^{23}$ Furthermore, both our interviews with firm executives and a review of several compensation plans used in these firms highlight the differences between how SOEs and wholly privatized firms in China implement the "yearly salary system.” The SOE firms often include factors such as occupational safety and health records in their performance indicators, while the fully privatized firms tend to be more focused on profit and stock performance. ${ }^{24}$

The procedures for determining SOEs’ executive compensation in China also imply that listed firms with greater state ownership and control will face more bureaucratic difficulty in reforming executive compensation, because they differ substantially from the procedures dictated by the market for effective incentive mechanisms. Specifically, the bureaucratic structure used till very recently for managing government shares in listed firms involves at least three separate government agencies. ${ }^{25}$ The CCP's Department of Organization (DOO), the State Economic and Trade Commission or the Industrial Commission (SETC), and the Ministry of Finance (MOF) were in charge of the personnel, operations, and asset management of all listed firms, respectively. Since each agency has its own line of duties and there is not much communication among them, the determination of executive compensation, which is mainly under the authority of the DOO, rarely depends on the firm's performance, which is evaluated by the SETC and MOF. Instead, in determining the level of compensation for top executive, the DOO uses the compensation level for government officials at the same rank as a reference and makes certain adjustments based on firm size and the executive’s education and working experience. Compensation for other executives will then be certain proportions of the top executive's pay level. For instance, the VP's salary will be $80 \%$ of the CEO's salary, and so on. The compensation figures will then be submitted to the

\footnotetext{
${ }^{23}$ See "Report on Chinese Entrepreneurs: Emergence and Development”(Zhongguo qiyejia chengzhang yu fazhan baogao), p27, issued by the Survey System for Chinese Entrepreneurs 2004.

${ }^{24}$ Dong and Putterman (2003) provide empirical support for a similar argument explaining why state ownership slows down the interest alignment process between top managers and shareholders, namely that stateowned enterprises and thus their top executives in transition economies are often required to pursue non-financial objectives such as employment provision. For a more formal theoretical argument, see Schmidt and Schnitzer (1993).

${ }^{25}$ It was only in March 2003 that the State Council decided to set up the State Asset Supervision and Administration Commission (SASAC), which would combine management of personnel, operations, and assets of state owned enterprises.
} 
board of directors, which will almost always approve them. Although sometimes the board of directors of a listed firm makes recommendations to give bonuses to executives based on good firm performance, these instances are far and few in between.

Note that this view contrasts with the belief that the gradual and piecemeal approach adopted by the Chinese government for reforming its SOEs will succeed in the long run without decreasing state ownership and control substantially. Specifically, the hypothesis implies that China's experiment with publicly listing its large firms without substantially decreasing state ownership and control is not helping the corporate governance of these firms significantly.

We are, however, also aware of several arguments that may imply several positive effects of government ownership on corporate governance. Large percentage of government shares may signal to the market that shareholders' wealth will not be expropriated and thus indicate lower uncertainty for domestic investors. ${ }^{26}$ In addition, substantial government ownership may prevent large scale state asset stripping and mitigate rabid rent-seeking behaviors of managers when markets are lacking. ${ }^{27}$ Finally, it is well known that private firms in China are inferior to SOEs in both their level of management and technology as well as the quality of their employees. ${ }^{28}$ Since superior incentive mechanisms are often initiated by capable executives who have superior managerial skills, it could then be argued that firms with greater state ownership and control are more capable of adopting the more efficient incentive measures including executive compensation reforms.

Previous empirical work has been focused on the effects of ownership structure on firm performance with mixed results. We contribute to the important policy debate by providing the first systematic evidence on the effects on executive pay-performance link (and thus the quality of corporate governance) of state ownership and control of listed firms. ${ }^{29}$

${ }^{26}$ See, for example, Perotti (1995) and Mok and Hui (1998).

27 See, for example, Jefferson (1998), Stiglitz (1997), and Lin, Cai and Li (1998)

${ }^{28}$ See, for instance, Naughton (1995) and Wu (2003).

${ }^{29}$ For a summary of arguments on the negative role played by government ownership in firm performance, see Shleifer (1998). For a model implying positive effects of state ownership in SOEs, see Perotti (1995). Megginson and Netter (2001) provide a comprehensive survey of empirical studies on the effects of government 
Though not reported in this paper due to space limitation, we also studied two additional issues.

First, earlier studies on the impact on firm performance of state ownership in China's listed firms often distinguish direct state ownership through state shares and indirect state ownership via legal person shares (Chen, 1998; Xu and Wang, 1999; and Sun and Tong, 2003). Thus, we examined whether executive payperformance link in China’s listed firms will become weaker as state ownership becomes more indirect with the expanding use of legal person shares. Second, recommendations for corporate governance reform in developing countries and transition economies often include the appointment of independent directors to the board of directors and the separation of the CEO position from the board chairmanship (Nam and Nam, 2004). As such, we investigated whether the appointment of "independent directors” to the board of directors in China’s listed firms is effective in making executive pay-performance link stronger; and whether the separation of the CEO position from the board chairmanship in China's listed firms is effective in making executive pay-performance link stronger (See Kato and Long (2004) for these additional results). ${ }^{30}$

\section{Data}

Accounting and financial data as well as executive compensation data are obtained from the China Stock Market and Accounting Research Database (CSMAR) developed by Shenzhen GTA Information Technology Company, while ownership structure data are assembled from the database developed by SinoFin Information Services. The CSMAR data set has been used in previous studies, ${ }^{31}$ yet on our reading of the literature, we are the first to use the Sinofin dataset in academic research. Data are available annually for 1998 through 2002 although information is more complete for later years.

versus private ownership on firm performance. Laffont and Tirole (1993) emphasize the importance of empirical studies as follows, "theory alone is thus unlikely to be conclusive in this respect."

${ }^{30}$ Another potentially important issue is the effect on pay-performance link of foreign ownership. However, foreign ownership of Chinese company stock is allowed only through B-shares, and such foreign ownership is still in its infancy (only about 3\% of total shares are owned by foreign investors according to our data).

${ }^{31}$ See, for instance, Sun and Tong (2003), Bai, et. al. (2004), and Bai, Liu, and Song (2003). 
The data allow us to study total cash compensation (including salary and bonus), and our empirical analysis based on cash compensation information leads to two main results. ${ }^{32}$ First, there are statistically significant sensitivities and elasticities of executive compensation with respect to shareholder value in China. Second, ownership structure of China's listed firms has important effects on payperformance link in these firms, with state ownership of China's listed firms weakening pay-performance link for top managers.

Among the several measures of executive compensation provided in the Sinofin database, TOP THREE EXECUTIVE AVERAGE PAY that includes total annual cash compensation for CEO and two other highest-paid executives (often vice CEOs) is the closest to what most prior studies on executive compensation have used (typically CEO pay) and thus will be the focus of our study. ${ }^{33}$ The data also contain information that enable us to provide important and fresh insights on one of the most vital policy issues in transitional economies, i.e., the importance of ownership restructuring in enterprise reforms. ${ }^{34}$ Specifically, the data allow us to calculate for each firm GVTSHARE (percentage of company shares owned by the state).

Table 1 reports descriptive statistics on the level of executive compensation, ownership structure and several other key firm characteristics, where all value variables are adjusted for inflation using CPI (FY1995=100) and are thus expressed in 1995-constant RMBs. These statistics were calculated based on a pooled cross-sectional time series dataset on 942 firms. ${ }^{35}$ They can be compared to prior studies such as

\footnotetext{
${ }^{32}$ According to the rules from the CSRC (China Securities Regulatory Commission) that regulates the content of listed firms' annual reports, all listed firms have been required to report executive compensation including salary and bonus. Unfortunately they are not required to report salary and bonus separately and hence we are unable to analyze these two main components of cash compensation separately as Kato and Kubo (2003) did for their study of Japanese CEO compensation.

${ }^{33}$ We also considered two other more aggregate measures of executive compensation, TOTAL EXECUTIVE PAY (total annual cash compensation for all directors, supervisors, and high-level executives) and AVERAGE EXECUTIVE PAY (TOTAL EXECUTIVE PAY divided by the number of all directors, supervisors and high-level executives). The results using these alternative cash compensation measures are similar to the ones reported in the paper although somewhat weaker and less significant as expected from such aggregate measures. These and other unreported results are available upon request from the corresponding author (tkato@mail.colgate.edu).

${ }^{34}$ See, for instance, Estrin (2002) and Jones and Mygind (2004).

${ }^{35}$ As is commonly done in the literature, we excluded five financial firms (mainly banks) from our sample.
} 
Kaplan (1994) for Japan and the U.S.; Kato and Kubo (2003) for Japan; and Kato, Kim and Lee (2004)

for Korea that report similar statistics.

In particular, while average cash compensation for top three executives in Chinese listed firms is much lower (RMB97,000 or approximately $\$ 12,000$ ) than that for their counterparts in Japan and Korea, the ratio of average top three executive pay/average worker pay (at around 12) is substantially higher in China. The ratio is also higher than in other transition economies. ${ }^{36}$ Similarly, the average executive in China's listed firms appears to be better paid relative to the average worker in manufacturing (with a ratio of around 7) than their counterparts in Japan and Korea. Using data from Kubo (2001) for Japan and Kato, Kim and Lee (2004) for Korea and the ILO average manufacturing worker wage, we found that the ratio of average executive pay to average manufacturing worker wage was 4.2 for Japan in 1995-96 and 5.6 for Korea in 1998-2001. However, the Chinese ratio as well as its executive pay is still considerably lower than the comparable U.S. figures. ${ }^{37}$

Several other key firm characteristics are also shown in Table 1. The average listed firm in China employed over 3,000 workers. Sales revenue of the average listed firm was 1.4 billions of 1995-constant RMBs and the market value of the average listed firm was 1.7 billions of 1995-constant RMBs. Over the period of 1998-2002, many listed firms in China experienced poor stock market performance. Thus, the average rate of inflation-adjusted stock return was negative 14 percent over the sample period. On the other hand, ROA (return on asset) was on average positive although small (0.01). The average probability of China’s listed firms reporting a negative before-tax profit was about 12 percent over 19982002. The average size of the board of directors and supervisors were 9.7 and 4.3 respectively whereas the average number of directors, supervisors and other top-level executives considered in calculating TOTAL EXECUTIVE PAY was 11.2, suggesting that there were a non-negligible number of directors and supervisors who were not paid by the firm. ${ }^{38}$

\footnotetext{
${ }^{36}$ See Jones and Kato (1996 and 1998) for Bulgaria, and Jones and Mygind (2004) for Estonia.

${ }^{37}$ See, for example, Kaplan (1994, Table 4) and Murphy (1999, Figure 1) for the comparable U.S. figures.

38 These are directors and supervisors working for the firm's largest shareholder firms (mostly SOEs) and thus paid by the "parent" firms. Since they are affiliated with related companies, they are not "independent
} 
Finally, data on ownership structure reveals that the public listing of SOEs in stock exchanges has not substantially reduced the dominance of state ownership. The average listed firm still has about 60 percent of its company stock owned by the state. ${ }^{39}$

In addition to cash compensation, two other prevalent components of executive compensation in China are restricted stocks and perquisites. As in most countries outside the U.S., the lack of data on these other types of executive compensation prohibits us from analyzing total executive compensation in China. For reasons to be discussed below, however, we expect the above results to be robust even when these other compensation components are considered.

In contrast to its prominent role in executive compensation in the U.S., stock option has yet to become a meaningful compensation alternative in China. No listed firms in China had adopted stock option as part of their executive compensation packages as of the end of 2002, the last year covered in our sample. ${ }^{40}$ And it was not until early 2003 when the CSRC chose two pilot firms to test run a stock option plan. ${ }^{41}$ Our discussion below, therefore, will focus on the implications of excluding equity ownership and perquisites from the analysis. We will first provide some estimates for their relative sizes compared with cash compensation and show that cash compensation is typically the largest component of total compensation for Chinese executives. Then we will explain why our main results will remain robust even if these components could be measured and included.

Data on equity ownership of executives that can be merged consistently with our top executive cash compensation data are presently unavailable. Nevertheless, for the period of 1999-2002 and a large proportion of the listed firms, the Sinofin data set allows us to estimate the value of company shares owned by the entire board of directors at about 70 percent of their total annual cash compensation, which

directors”

${ }^{39}$ To abstract from issues related to market segmentation, we excluded from our study the around 3\% of Chinese corporate shares denominated in foreign currencies and available only to foreign investors, commonly referred to as B-shares.

${ }^{40}$ China Industry and Commerce Times, zhonghua gongshang shibao (2002-11-07).

${ }^{41}$ International Finance News, guoji jinrong bao (2003-4-28). 
is a considerably lower figure than what Kaplan (1994) estimates for Japan (117 percent). ${ }^{42}$ The relatively modest size of equity ownership in Chinese executive’s total compensation can be further illustrated as follows. The typical contract for top executives in China is three-year long, and thus a top executive contract can be considered worth three years of annual cash compensation plus market value of his/her equity ownership. In other words, a director's stock holdings typically amount to $23.3 \%$ of his total wealth generated by being appointed to the top executive position.

According to popular beliefs in China, the importance of corporate perquisites is another distinctive feature of executive compensation in China. Although anecdotes abound that suggest perquisites to be an important component of total compensation for Chinese executives, there is no empirical evidence on the relative size of these perquisites. We, therefore, attempt to provide a preliminary estimate of the importance of such perquisites using available information. The most common types of corporate perquisites in China include vehicle usage and housing subsidy. ${ }^{43}$

Since vehicle usage is the most cited perk for corporate executives as well as government officials in China, we start with estimating its size. The annual lease of a Santana, the typical choice of Chinese top executives, costs about 36,000 RMB. Assuming the executive uses the corporate vehicle for personal usage one third of the time, most likely an over-estimate, this adds 12,000 RMB to the executive's cash compensation. ${ }^{44}$ Since the average cash compensation for Chinese executives studied in this paper is about $100,000 \mathrm{RMB}$, vehicle usage amounts to $12 \%$ of cash compensation for Chinese executives.

For housing subsidy, Liu (2004) refers to 3,000 RMB per month as an upper bound estimate, adding 36,000 RMB to a top Chinese executive’s cash compensation. Much lower amount of housing

\footnotetext{
42 The use of stock option was also limited in Japan until recently. Considering all stock-based compensation forms including stock option, executive compensation in both China and Japan are far more cashbased than the U.S.

${ }^{43}$ Other types of executive perquisites in China include travel expenses, business gifts, and business attire expenses. These perks tend to have much lower values, according to our interviews with Chinese executives in the summer of 2004.

${ }^{44}$ It is estimated that one third of government vehicle usage is devoted to the top government official executive's personal usage, with the rest devoted to official business and the driver in equal proportions. See "Public Finance Reform is the Key to Government Vehicle Usage Reform,” June 17, 2005 edition of China Youth Daily (Zhongguo Qingnian Bao).
} 
subsidy, however, seems to be the norm. Three firms we interviewed in the summer of 2004 in Sichuan Province give $5 \%$ to $6 \%$ of annual salary as the amount of housing subsidy. Using 100,000 RMB as the average annual salary, these numbers translate to much lower amounts of housing subsidy, 5,000 to 6,000 RMB. Thus, the amount of housing subsidy ranges from $5 \%$ to $36 \%$ of Chinese executives' cash compensation. These numbers give a range of the size of executive perks in China, with the lower bound at $17,000 \mathrm{RMB}$, or $15 \%$ of the total annual compensation for Chinese executives (cash compensation plus perquisites) and the upper bound at 48,000 , or $32 \%$ of total annual compensation. ${ }^{45}$ Although perquisites are hardly negligible, cash compensation remains the most important component of total compensation for Chinese top executives.

In short, in China's listed firms cash compensation (salary and bonus) appears to remain the most dominant form of executive compensation, and any study of executive compensation in China's listed firms ought to consider at least cash compensation. Furthermore, we expect that the inclusion of non-cash forms of compensation will not change our main results at least qualitatively. In fact, inclusion of equity ownership is likely to strengthen our main conclusions. First of all, overall we find statistically significant pay-performance link for top management in China’s listed firms when considering only cash compensation. Because the value of company stock is directly related to stock market performance of the firm, including equity ownership of executives will make executive pay-performance link even more significant. In other words, the pay-performance sensitivity and elasticity that we report can be regarded as lower bounds on the sensitivity and elasticity of total executive compensation in China's listed firms.

Secondly, we find executive pay-performance link to be weaker for listed firms with greater state ownership and control than other listed firms. This negative relationship between state ownership and pay-performance link is likely to become more pronounced if we include equity ownership of executives since equity ownership of executives tends to be more restricted in listed firms with greater state

${ }^{45}$ According to Tower-Perrin's Worldwide Total Remuneration Survey, in 2001-2002, perquisites accounted for 11 percent of the sum of cash compensation and perquisites for the U.S.; 9 percent for Japan and the U.K.; and 8 percent for South Korea. Unfortunately, the Tower-Perrrin data are not comparable to our Chinese data and our preliminary estimate on the value of perquisites in China's listed firms ought to be compared to this international evidence with caution. 
ownership and control. ${ }^{46}$ Put differently, sensitivity and elasticity of total compensation to stock market performance in firms with greater state ownership and control are likely to be smaller than those in other firms for two reasons. First, sensitivity and elasticity of cash compensation to stock performance are smaller in firms with greater state ownership. Second, compensation in equity ownership, which is naturally highly sensitive to stock performance, is less common in firms with greater state ownership.

The effects of omitting perquisites from executive compensation are a little more complicated, but we expect our main results to be robust even when perquisites are considered. While no information is available on the allocation of perquisites to executives in China's listed firms, we do know that these perks are usually linked to job titles and position ranks in the company. Because the relationship between perquisites and job titles (or position ranks) does not change much over the years, these perks do not vary much from year to year. ${ }^{47}$ Therefore, excluding perks will not bias our estimates on pay-performance sensitivity in the first-differenced models we use (see the next section for more details on our econometric specifications). ${ }^{48}$

For pay-performance elasticity, however, the exclusion of perquisites from the compensation measure may lead to an over-estimation when perks do not change with firm performance, although adding perks will not eliminate the significant positive pay-performance elasticity estimated in this paper. ${ }^{49}$ In addition, the relative size of perquisites in executives' total compensation suggests that such an over-estimation is of modest magnitude. Given that perks amount to $17 \%$ to $48 \%$ of executive cash

\footnotetext{
${ }^{46}$ Chinese government has refused to allow state shares to be used in equity holding plans, and as a result listed firms with higher percentage of state shares find it more difficult to issue company stock as part of executive compensation package (See the 2003-07-30 issue of Shanghai Securities News, shanghai zhengquan bao).

${ }^{47}$ Results reported in Rajan and Wulf (2004) suggest that this is also the case in the U.S.

${ }^{48}$ For instance, see Liu and Otsuka (2004) that reports helpful institutional information on compensation packages provided for steel industry top executives in four provinces in China. Our field work in four Chinese cities during the summer of 2004 also confirms this point.

${ }^{49}$ Let $y_{t}$ be the executive compensation in period $t, y_{t-1}$ the executive compensation in period $t-1$, and $k$ be the value of perks that does not vary in time. Because $\left(y_{t}+k\right) /\left(y_{t-1}+k\right)$ is a decreasing function in $k$ as long as $y_{t}>y_{t}$ 1 and $k>0$, omitting $k$ will lead to the over-estimation of the growth rate of executive compensation, $\log \left(\left(y_{t}+k\right) /\left(y_{t-}\right.\right.$ $\left.{ }_{1}+k\right)$ ), and consequently the estimated pay-performance elasticity. We thank our referee for pointing out this issue.
} 
compensation, the growth rate of cash compensation plus perks may be overestimated by $13.4 \%$ to $30.5 \%$. In other words, the pay-performance elasticity will be overestimated by about $30 \%$ at the most. ${ }^{50}$

As for our second main result on the effect of state ownership, the overestimation of elasticity may be more severe for state controlled listed firms, because they bear more resemblance to government agencies in China and hence their executives enjoy more perks than privately controlled firms. This suggests that state-private difference in pay-performance elasticity may be larger than estimated in this paper, because perks that are insensitive to firm performance tends to constitute a larger proportion of executive compensation in state controlled listed firms than in privately controlled ones. ${ }^{51}$ In other words, considering perquisites are more likely to strengthen our key finding that pay-performance link is weaker for state controlled listed firms.

\section{$\underline{\text { IV. Results }}$}

As a prelude to the full econometric analysis, we first present some Box-Whisker plots to explore how executive compensation relates to firm performance, using the growth rate of TOP THREE EXECUTIVE AVERAGE PAY or $\Delta \ln Y$ as the compensation measure. In the plots shown in Figures 1-4, the upper and lower ends of the whiskers indicate the UAV (upper adjacent value) and the LAV (lower adjacent value), the upper and lower boundaries of the box indicate the upper quartile and the lower quartile, and “+” indicates the medium. ${ }^{52}$ In addition, we also indicate the mean value by “-”. The Box-

\footnotetext{
${ }^{50}$ These numbers are calculated using $\log \left(\left(y_{t}+k\right) /\left(y_{t-1}+k\right)\right)$, with the mean values of top executive pay and its annual change as well as the range of values of executive perks estimated above.

${ }^{51}$ Even in cases where perks vary over time, the changes tend to fall in either of the following two categories. First, perquisites may increase over time for all firms; and second, perquisite increases may be positively correlated with firm performance. Omission of the first type of perquisite growth may lead to under-estimation of the growth rate of executive compensation, while omission of the second type of perk increase may lead to underestimation of the pay-performance sensitivity and elasticity for Chinese top executives. Consequently, to the extent that increases in perquisites over time of these two types are important, our results presented below offer lowerbound estimates for the growth rate of executive compensation as well as the pay-performance sensitivity and elasticity in China.

${ }^{52}$ We follow these steps in order to produce a box plot: (i) calculate the median m; (ii) calculate the first and third quartile Q1 and Q3; (iii) compute the inter-quartile range IQR=Q3-Q1; (iv) find the lower fence $\mathrm{LF}=\mathrm{Q} 1-1.5 * \mathrm{IQR}$; (v) find the upper fence $\mathrm{UF}=\mathrm{Q} 3+1.5 * \mathrm{IQR}$; (vi) find the lower adjacent value $\mathrm{LAV}=$ smallest value in the data that is greater or equal to the lower fence; (vii) find the upper adjacent value UAV=largest value
} 
Whisker plots using four alternative firm performance measures: stock return, sales growth, ROA growth, and the presence of negative profit are presented in Figures 1-4, respectively. To see how the distribution of $\Delta \ln \mathrm{Y}$ differs depending on firm performance, we produce such Box-Whisker plots for firms with below medium performance and those with above medium performance in Figures 1-3. In Figure 4, we contrast firms with negative pre-tax income with those with positive pre-tax income.

Overall, the Box-Whisker plots appear to suggest that better-performing firms have higher upper quartile values, medium values, and mean values for growth rate of their executive compensation. A standard two-sample test of means establishes that the differences in the mean values between the two groups of firms are statistically significant at least at the $10 \%$ level.

To investigate with more precision the suggestive finding from the Box-Whisker plots, we undertake a number of econometric exercises. We begin with the OLS estimates of our baseline sensitivity and elasticity equations, Eq. (1) and Eq. (2). Note that both pay and performance variables are first-differenced, so all firm fixed effects that may affect the level of pay are controlled for. We used firstdifferences to facilitate comparison with prior studies that tend to use first differences rather than estimating fixed effects directly. This implies that only firms for which data are available for at least two consecutive years can be used. Among the 918 firms for which we have data for at least one year over the period of 1998-2002, 827 firms provided data for at least two consecutive years. A standard two-sample test of means establishes that the new sample of 827 firms does not differ significantly from the original sample of 918 firms with regard to all the compensation and key firm characteristic variables listed in Table 1. The bulk of observations in our pooled cross-sectional time series data used for the firstdifferenced regressions are for 2001-2002 since most of the 827 firms do not provide detailed compensation data prior to 2001. Table 2 presents summary statistics of variables used in the regressions.

Over the sample period the average annual pay raise was 14 thousands of 1995-constant RMB per individual. Likewise, executive compensation rose by 25 percent per year in real terms over the sample

in the data that is smaller or equal to the upper fence; (viii) any value outside the LAV or UAV is considered an outlier, which are not shown in our plots. 
period. The table also shows an average fall of 226 thousands of 1995-constant RMB in shareholder value (V) each year and an average fall of 2.6 percentage-points in ROA each year over the sample period. To be consistent, average annual stock return over the sample period was -11.8 percent. However, sales grew over the sample period by a robust 18.3 percent per year in real terms. Finally, the sectoral composition of the final sample of firms to be used for our econometric analysis is as follows: (i) 62 percent of them are in the manufacturing sector; (ii) 15 percent in the commercial sector; (iii) 12 percent in the public utility sector; (iv) 4 percent in the primary sector; and (v) the rest in other sectors.

Columns (i) and (ii) of Table 3 presents the OLS estimates of Eq. (1) and Eq. (2). ${ }^{53}$ The estimated sensitivity and elasticity of pay with respect to shareholder value are positive and statistically significant at the 1 percent level and at the 5 percent level, respectively. The size of the estimated sensitivity suggests that a 1000 RMB increase in shareholder value yields a 0.045 RMB increase per executive in annual cash compensation for the highest-paid three executives.

Our estimate on top management pay sensitivity to shareholder value appears to be greater than what Jensen and Murphy (1990) and Murphy (1999) found for the U.S. For example, Murphy (1999) reports that a 1000 dollar increase in shareholder value leads to a 0.014 dollar increase in CEO's annual cash compensation for S\&P 500 Industrials in the U.S. in the first half of the 1990s. We believe that the sensitivity of pay with respect to shareholder value is higher in China than in the U.S. in part due to the inverse relationship between pay-performance sensitivities and firm size (see Gibbons and Murphy, 1992, and Murphy 1999). Smaller firms tend to have larger sensitivities and Chinese listed firms are generally substantially smaller than U.S. listed firms. ${ }^{54}$

However, more importantly, the different compositions of executive compensation between China and the U.S. may account for the higher pay-performance sensitivities observed for Chinese listed

\footnotetext{
${ }^{53}$ Previous U.S. studies such as Jensen and Murphy (1990) and Murphy (1999) report very low $\mathrm{R}^{2}$ statistics (typically well below 0.1). This is in large part due to the fact that the literature typically uses first differences instead of estimating fixed effects directly.

${ }^{54}$ To this end, comparing our sensitivity estimates to what Kato and Kubo (2003) report for Japanese CEOs may be useful since Japanese listed firms are substantially smaller than U.S. listed firms. Reassuringly, our Chinese sensitivity estimates are closer to the Japanese estimates of 0.034 .
} 
firms. While they are rarely available for executives in listed firms in China, stock option plans are widely used for top executives in U.S. corporations. When stock options were taken into account in executive compensation, for instance, Jensen and Murphy (1990) estimated that a 1000 dollar increase in shareholder value lead to a 0.307 dollar increase in CEO's total compensation for 73 U.S. manufacturing firms between 1969 and 1983, implying much higher pay-performance sensitivities in U.S. firms than in China. Murphy (1999) further reports that since then total sensitivities have risen rapidly and that the sharp increase in total sensitivities in the 1990s was mostly due to the rising use of stock options. ${ }^{55}$

Since pay-performance elasticities are relatively invariant to firm size, for international comparisons of pay-performance relations for executives, pay-performance elasticities may be particularly useful. As Column (ii) of Table 3 shows, the size of our estimated elasticity suggests that a 10 percent increase in shareholder value results in 1.7 percent increase in annual cash compensation for the highest-paid three executives. Our elasticity estimates are greater than what Kato and Kubo (2003) report for CEOs of listed firms in Japan in 1986-1995 and what Murphy (1999) reports for CEOs of S\&P 500 Industrials in the U.S. in the 1970s (yet not as high as what he reports for later years or the 1980s and 1990s). ${ }^{56}$

Columns (iii) and (iv) of Table 3 present a robustness test concerning year effects such as time trend, technological change and other macroeconomic shocks that are common to all firms. Reassuringly controlling for such year effects make our estimates on pay-performance link even more significant. Specifically, the estimated sensitivity and elasticity are both positive and statistically significant at the 1 percent level. ${ }^{57}$

\footnotetext{
${ }^{55}$ Thus, much of the recent literature on U.S. executive compensation tends to focus on the issue of stock options. See, for example, Hall and Murphy (2003) and Bebchuk and Fried (2003) for succinct discussions on the recent literature which tends to focus on stock options.

${ }^{56}$ Again, one ought not to conclude that Chinese executives are faced with a greater incentive to pursue the interests of shareholders than U.S. executives since the bulk of incentives for U.S. executives are in the form of stock option rather than in cash compensation.

${ }^{57}$ In the literature there appears to be no strong consensus on the use of year dummy variables. For example, Kaplan (1994) considers year dummy variables whereas Murphy (1999) does not.
} 
Some prior studies on executive compensation (especially in countries outside of the U.S.)

consider alternative performance measures such as accounting measures and estimate "semi-elasticities" of pay with respect to such alternative performance measures. ${ }^{58}$ Following prior studies on other Asian countries (Japan and Korea), we estimate such "semi-elasticities” of pay with respect to four alternative performance measures. ${ }^{59}$ They are: (i) $R_{\text {it }}$ (=stock return); (ii) $S_{\text {it }}=$ rate of growth of sales of Firm i from Year t-1 to Year t (in percent); ${ }^{60}$ (iii) $\Delta \mathrm{P}_{\text {it }}=$ change in ROA (pre-tax profit/assets ratio) of Firm i from Year t-1 to Year t; ${ }^{61}$ and (iv) $\mathrm{N}_{\mathrm{it}}=1$ if Firm i's pre-tax profit is negative in Year t, 0 otherwise. ${ }^{62}$

The OLS estimates of such semi-elasticities are reported in Table 4. To be consistent with prior attempts to estimate such “semi-elasticities” (such as Kaplan, 1994), we include year dummy variables. Consistent with our pay-performance sensitivity and elasticity estimates above, the estimated coefficients on R (or "semi-elasticities” of pay with respect to stock return) are positive and statistically significant and the magnitude of the estimated semi-elasticity is comparable to those found in Japan and Korea. The estimated coefficient on S is also positive and statistically significant, with the size of the estimated semielasticity somewhat lower than what has been reported for Japan yet substantially higher than what has been reported for Korea. ${ }^{63}$ Turning to accounting profitability measures, it appears that Chinese executives are not penalized for weak showing of ROA, nor are they rewarded for strong showing of ROA, although they do seem to be penalized when the firm makes negative pretax profit. Finally, the

\footnotetext{
${ }^{58}$ See Rosen (1990) for the origin of the term "semi-elasticity."

${ }^{59}$ See, for example, Kaplan (1994), Kubo (2001), and Kato and Kubo (2003) for Japan; Kato, Kim and Lee (2004) for Korea.

${ }^{60}$ We also try employment growth yet find no statistically significant link of employment growth to executive pay growth.

${ }^{61}$ Sun and Tong (2003) argue that ROA is not an appropriate accounting performance measure due to a peculiar regulatory rule in China's stock market. Because listed firms in China are allowed to have rights issue up to $30 \%$ of their outstanding stocks annually and many companies take advantage of such a rule to increase equity capital even in the absence of investment opportunities. ROA, which decreases mechanically with such rights issue, does not reflect accurately the profitability of the firm. Instead, Sun and Tong (2003) suggest the use of ROS, or return on sales. We also use ROS instead of ROA in the regressions and obtain results very similar to those presented below. In addition, we try ROE (Return On Equity) and find equally similar results.

${ }^{62}$ Kaplan (1994) also considered lagged performance variables. We too considered such lagged performance variables and found that our estimates without such lagged performance variables are robust. As such, our results do not appear to depend on the timing between an observed value for firm performance and the determination of executive compensation.

${ }^{63}$ See Kaplan (1994) and Kato, Kim and Lee (2004) for comparable estimates on the "semi-elasticity" of executive pay with respect to alternative firm performance measures in Japan and Korea.
} 
results do not change even when various alternative performance measures are considered simultaneously, pointing to the robustness of the results.

We now turn to the effects of ownership structure on how executive compensation is determined. ${ }^{64}$ Specifically, to discern the impact on managerial contracts and incentives of ownership structure, we will first augment the standard pay-performance sensitivity and elasticity equations, Eq. (1) and Eq. (2), with G (percentage stock owned by the state) and an interaction term involving $G$ and firm performance.

Columns (i) and (ii) of Table 5 presents the OLS estimates of such augmented pay-performance sensitivity and elasticity equations. ${ }^{65}$ First, the estimated coefficient on the interaction terms in the sensitivity equation is negative and statistically significant at the 1 percent level, suggesting that payperformance sensitivities become stronger as the percentage of stock owned by the state falls. The magnitude of the impact of weakening state control is rather substantial. For example, a 1-percentage point decrease in $\mathrm{G}$ will result in an increase in the pay-performance sensitivity by 0.003 for the highestpaid three executives. This is hardly negligible, considering the estimated pay-performance sensitivities in this study as well as in earlier studies elsewhere range from 0.014 (the U.S.) to 0.034 (Japan) to 0.054 (China). ${ }^{66}$ The negative impact on pay-performance link of state ownership is robust to the alternative elasticity specification and the estimated coefficient on the interaction term in the elasticity equation is also negative and statistically significant at the 5 percent level, as shown in Column (ii) of Table 5. Columns (iii) and (iv) of the table provide an account of whether the significant relationship between state ownership and pay-performance link obtained earlier changes when we add size and sector

\footnotetext{
${ }^{64}$ There is a growing literature on the link between ownership structure and executive compensation in advanced industrialized nations. See, for example, Core, Holthausen, and Larcker (1999), Ke, Petroni, and Safieddine (1999), Harvey and Shrieves (2001), Bertrand and Mullainathan (2001), Cyert, Kang and Kumar (2002) and Hartzell and Starks (2003) for the U.S.; Conyon (1997), Cosh and Hugh (1997), and Cragg and Dyck (2003) for the U.K.; Kato (1997) for Japan; Elston and Goldberg (2002) for Germany; Brunello, Graziano, and Parigi (2001) for Italy; and Randoy and Nielsen (2002) for Norway and Sweden. For transition economies, see for instance, Jones and Kato (1996, 1998) for Bulgaria; Jones and Mygind (2004) for Estonia; and Eriksson (2004) for Czech and Slovak Republics. variables.

${ }^{65}$ We report the results with year dummy variables yet we found similar results without such year dummy

${ }^{66}$ See, Murphy (1999) and Kato and Kubo (2003).
} 
as well as interaction terms involving performance and such additional covariates. Specifically, we use book value asset (A) to measure firm size ${ }^{67}$ and five sector dummy variables (primary, manufacturing, public utility, commercial, and all other) to account for possible industry effects. ${ }^{68}$ The summary statistics of these additional covariates are included in Table 2. Reassuringly these two columns confirm that the significant negative relationship between state ownership and pay-performance sensitivity/elasticity is insensitive to whether we consider size and sector (and interaction terms involving performance and these additional covariates).

We interpret the negative and significant coefficients on the interaction terms involving state ownership and firm performance as evidence for the negative impact on executive pay-performance link (and hence the quality of corporate governance) of state ownership. However, an alternative interpretation reversing the causality is possible. In other words, in their attempt to attract more capital from private investors including foreign investors, listed firms improve the quality of their corporate governance and signal such an improvement to private investors by making their executive payperformance link stronger. As a result, those firms with stronger pay-performance link will end up attracting more private capital, making the percentage of stock owned by the state lower.

For several reasons, we think this reverse causality signaling interpretation is less relevant to listed firms in China. First, ownership structure appears to be less endogenous in the Chinese context because in general the introduction of different ownership structure is often policy-induced and motivated by political considerations rather than economic logic. For instance, Han (1997) discusses how the quota system plagued with political idiosyncrasies determines which companies get listed on the stock market and how many shares can be issued. In addition, reassuringly Sun and Tong (2003) report econometric evidence that state share ownership of Chinese listed firms is not significantly affected by their prior firm

${ }^{67}$ Following Schaefer (1998), we also considered market value of the firm in addition to A. We found no discernable difference. As a preliminary exercise, we calculated correlation coefficients between $\mathrm{G}$ and size (measured by asset and market value). Both asset and market value are found to be significantly correlated with G at the 10 percent level, suggesting a need to control for size.

${ }^{68}$ We drop the other sector category as a reference in the regressions. 
performance. Furthermore, more recently Wei, Xie, and Zhang (2005) and Guo and Yao (2005) provide evidence largely consistent with Han (1997) and Sun and Tong (2003).

Moreover, to confirm that the reverse causality signaling interpretation may be less relevant to the Chinese listed firms studied here, we consider two additional specifications. First, we re-estimate our augmented sensitivity and elasticity equations, using a lagged state ownership variable, $\mathrm{G}_{\mathrm{it}-1}$, with the results summarized in Columns (v) and (vi) of Table 5. Reassuringly even after controlling for size and sector effects, the percentage of stock owned by the state in the previous year is significantly related to the current pay-performance link, which is more consistent with the causality from ownership structure to pay-performance link than the reverse causality from pay-performance link to ownership structure.

Second, we limit our sample to include those listed firms in government targeted industries where they have guaranteed access to capital through the state and hence have little need to signal the high quality of corporate governance (and strong pay-performance link) to private investors in order to attract private capital. ${ }^{69}$ For these firms, the alternative signaling interpretation is less relevant. As the last two columns of Table 5 show, in spite of a substantially reduced sample size (n=129), we still obtain statistically significant and negative coefficient on the interaction term involving firm performance and G in both the sensitivity and elasticity specifications even after accounting for the size and sector effects.

Overall, we believe we have obtained systematic evidence on the negative effect on executive pay-performance link of state ownership in China's listed firms. In addition, as mentioned before, given that firms with lower percentage of government shares tend to offer more company shares to their top executives, these results are expected to be robust even if equity holdings are taken into consideration when computing executive total compensation.

\footnotetext{
${ }^{69}$ Following the "Decision of the $4^{\text {th }}$ Plenum of the CCP's $15^{\text {th }}$ Congress, as cited in Xiao (2003), we consider raw material and energy, public utilities, banking and finance, pharmaceutical, and agriculture as the "government targeted industries" where access to capital is guaranteed by the state.
} 


\section{$\underline{\text { V. Conclusions and Policy Implications }}$}

Given that the goal of China's SOE reform is to transform SOEs into modern corporations that can compete successfully in the global market, measuring the quality of corporate governance for Chinese firms will help evaluate the effectiveness of the reform. Because executive compensation is a major component of the firm's incentive structure and at the core of the firm's corporate governance, our study on executive compensation helps evaluate the quality of corporate governance and in turn the success of SOE reform in China. Furthermore, both economic theory and empirical evidence show that an efficient compensation system involves close links between firm performance and executive compensation, therefore we attempt to determine the existence and magnitude of such link in China's listed firms in this study.

We have found consistently for firms listed in China’s emerging stock market statistically significant sensitivities and elasticities of cash compensation for the highest-paid executives with respect to shareholder value. The size of the estimated sensitivities and elasticities is comparable or greater than what has been found for other countries (particularly the U.S., Japan and Korea). Among other firm performance measures, we have found evidence that sales growth is linked to executive compensation in China's listed firms and that Chinese executives are penalized for making negative profit although they are neither penalized nor rewarded for changes in profit insofar as it is positive.

The significant pay-performance link for top management in China’s listed firms is overall encouraging news for current policy makers in China, who consider public listing in the stock market as a key mechanism of achieving such a goal for large SOEs.

However, not all news is good. Perhaps most importantly, we have found that government ownership of China's listed firms is weakening pay-performance link for top managers and thus possibly making China’s listed firms less effective in solving the agency problem.

These findings have important implications for China’s enterprise reform. Listed firms in China seem to be aligning the interests between top managers and shareholders to a certain degree and such an interest alignment is stronger when accompanied by a reduction in government ownership of listed firms 
and thus a better defined bundle of property rights. Therefore, ownership restructuring may be needed for China to successfully transform its SOEs to efficient modernized corporations and reform its overall economy.

Finally, an alternative way to align the interests between top executives and shareholders is to tie their employment to firm performance. A full understanding of the incentive structure of top executives in China's listed firms will thus require an examination of the link between executive turnover and firm performance and how such a link is affected by ownership structure. To do so will require the collection of new data on top executive turnover in China's listed firms that can be matched with our CSMAR and Sinofin databases, a project we plan to do in the near future. ${ }^{70}$

${ }^{70}$ There is yet another growing literature on executive turnover. Some of the literature examine specifically the link between executive turnover-performance sensitivities and ownership structure in industrialized countries: for instance, see Denis, Denis, and Sarin (1997) on the U.S.; Kaplan and Minton (1994), Kang and Shivdasani (1995), and Morck and Nakamura (1997) on Japan; Volpin (2002) on Italy; and Campbell, II. and Keys (2002) on Korea. 


\section{References}

Aghion, Philippe; Olivier Jean Blanchard and Robin Burgess. 1994. "The Behaviour of State Firms in Eastern Europe, Pre-Privatisation." European Economic Review 38 (June): 1327-49.

Ang, James S. and Richard L. Constand. 1997. "Compensation and Performance: The Case of Japanese Managers and Directors." Journal of Multinational Financial Management 7 (December): 275304.

Bai, Chong-En; Qiao Liu; Joe Lu; Frank M. Song and Junxi Zhang. 2004. "Corporate Governance and Market Valuation in China." Journal of Comparative Economics 32 (December): 599-616.

Bebchuk, Lucian Arye and Jesse M. Fried. 2003. "Executive Compensation as an Agency Problem." Journal of Economic Perspectives 17 (Summer): 71-92.

Bertrand, Marianne and Sendhil Mullainathan. 2001. "Are CEOs Rewarded for Luck? The Ones without Principles Are." Quarterly Journal of Economics 116 (August): 901-32.

Black, Bernard. 2001. "The Corporate Governance Behavior and Market Value of Russian Firms." Emerging Markets Review 2 (June): 89-108.

Black, Bernard S; Jang Hasung and Woochan Kim. 2003. "Does Corporate Governance "Predict Firms' Market Values? Evidence from Korea." John M. Olin Program in Law and Economics Working Paper no. 237, Washington University, Olin School of Business.

Bonin, John P. 1976. "On the Design of Managerial Incentive Structures in a Decentralized Planning Environment." American Economic Review 66 (September): 682-87.

Brunello, Giorgio; Clara Graziano and Bruno Parigi. 2001. "Executive Compensation and Firm Performance in Italy." International Journal of Industrial Organization 19 (January): 133-61.

Campbell, Terry L., II and Phyllis Y. Keys. 2002. "Corporate Governance in South Korea: The Chaebol Experience." Journal of Corporate Finance: Contracting, Governance and Organization 8 (October): 373-91.

Chang, Chun; Brian P. McCall and Yijiang Wang. 2003. "Incentive Contracting Versus Ownership Reforms: Evidence from China's Township and Village Enterprises." Journal of Comparative Economics 31 (September): 414-28.

Chen, Y. 1998. "Ownership Structure and Corporate Performance: Some Chinese Evidence." Unpublished manuscript, San Francisco State University.

Conyon, Martin J. 1997. "Corporate Governance and Executive Compensation." International Journal of Industrial Organization 15 (July): 493-509.

Core, John E.; Robert W. Holthausen and David F. Larcker. 1999. "Corporate Governance, Chief Executive Officer Compensation, and Firm Performance." Journal of Financial Economics 51 (March): 371-406.

Cosh, Andy and Alan Hughes. 1997. "Executive Remuneration, Executive Dismissal and Institutional Shareholdings." International Journal of Industrial Organization 15 (July): 469-92.

Cragg, Michael I. and I. J. Alexander Dyck. 2003. "Privatization and Management Incentives: Evidence from the United Kingdom." Journal of Law, Economics, and Organization 19 (April): 176-217.

Cyert, Richard M.; Sok-Hyon Kang and Praveen Kumar. 2002. "Corporate Governance, Takeovers, and Top-Management Compensation: Theory and Evidence." Management Science 48 (April): 45369.

Denis, David J.; Diane K. Denis and Atulya Sarin. 1997. "Ownership Structure and Top Executive Turnover." Journal of Financial Economics 45 (August): 193-221.

Dewatripont, Mathias and Gerard Roland, 1997, Transition as a Process of Large-Scale Institutional Change, In Advances in Economics and Econometrics: Theory and Applications: Seventh World Congress. Volume 2 Cambridge; New York and Melbourne: Cambridge University Press

Dong, Xiao-Yuan and Louis Putterman. 2003. "Soft Budget Constraints, Social Burdens, and Labor Redundancy in China's State Industry." Journal of Comparative Economics 31 (March): 110-33.

Elston, Julie Ann and Lawrence G. Goldberg. 2003. "Executive Compensation and Agency Costs in Germany." Journal of Banking and Finance 27 (July): 1391-410. 
Eriksson, Tor. 2004. "Managerial Pay and Executive Turnover in the Czech and Slovak Republics." Paper presented at the 2004 ASSA Meetings, San Diego, Jan. 3-5

Estrin, Saul. 2002. "Competition and Corporate Governance in Transition." Journal of Economic Perspectives 16 (Winter): 101-24.

Gibbons, Robert, 1997, Incentives and Careers in Organizations, In Advances in Economics and Econometrics: Theory and Applications: Seventh World Congress. Volume 2 Cambridge; New York and Melbourne: Cambridge University Press

Gibbons, Robert and Kevin J. Murphy. 1992. "Optimal Incentive Contracts in the Presence of Career Concerns: Theory and Evidence." Journal of Political Economy 100 (June): 468-505.

Groves, Theodore; Yongmiao Hong; John McMillan and Barry Naughton. 1995. "China's Evolving Managerial Labor Market." Journal of Political Economy 103 (August): 873-92.

Guo, Kai and Yang Yao. 2005. "Causes of Privatization in China: Testing Several Hypotheses." Economics of Transition 13 211-38.

Hall, Brian J. and Kevin J. Murphy. 2003. "The Trouble with Stock Options." Journal of Economic Perspectives 17 (Summer): 49-70.

Han, Zhiguo, 1997, On the Development of China's Stock Market, In The Future Road of State Owned Enterprises eds. F. Dong, Y. Li and Z. Han, Beijing, P.R. China: Economic Science Publishing

Hartzell, Jay C. and Laura T. Starks. 2003. "Institutional Investors and Executive Compensation." Journal of Finance 58 (December): 2351-74.

Harvey, Keith D. and Ronald E. Shrieves. 2001. "Executive Compensation Structure and Corporate Governance Choices." Journal of Financial Research 24 (Winter): 495-512.

Ickes, Barry W. and Larry Samuelson. 1987. "Job Transfers and Incentives in Complex Organizations: Thwarting the Ratchet Effect." RAND Journal of Economics 18 (Summer): 275-86.

Jefferson, G. 1998. "China’s State Enterprises: Public Goods, Externalities, and Coase." American Economic Review 88 428-32.

Jefferson, Gary H.; Su Jian; Jiang Yuan and Yu Xinhua. 2003. "The Impact of Shareholding Reform on Chinese Enterprise, 1995-2001." William Davidson Institute Working Paper no. 542, University of Michigan.

Jensen, Michael C. and Kevin J. Murphy. 1990. "Performance Pay and Top-Management Incentives." Journal of Political Economy 98 (April): 225-64.

Joh, Sung Wook. 1999. "Strategic Managerial Incentive Compensation in Japan: Relative Performance Evaluation and Product Market Collusion." Review of Economics and Statistics 81 303-13.

Jones, Derek C. and Takao Kato. 1998. "Chief Executive Compensation During Early Transition: Further Evidence from Bulgaria." William Davidson Working Paper no. 146, University of Michigan. . 1996. "The Determinants of Chief Executive Compensation in Transitional Economies: Evidence Form Bulgaria." Labour Economics 3 (October): 319-36.

Jones, Derek C. and Niels Mygind. 2004. "Majority Ownership and Executive Compensation." Paper presented at 2004 ASSA Meetings, San Diego, January 3-5

. 2004. "Majority Ownership and Executive Compensation." Paper presented at the 2004 ASSA Meetings, San Diego.

Kang, Jun-Koo and Anil Shivdasani. 1995. "Firm Performance, Corporate Governance, and Top Executive Turnover in Japan." Journal of Financial Economics 38 (May): 29-58.

Kaplan, Steven N. 1994. "Top Executive Rewards and Firm Performance: A Comparison of Japan and the United States." Journal of Political Economy 102 (June): 510-46.

. 1994. "Top Executives, Turnover, and Firm Performance in Germany." Journal of Law, Economics, and Organization 10 (April): 142-59.

Kaplan, Steven N. and Bernadette A. Minton. 1994. "Appointments of Outsiders to Japanese Boards: Determinants and Implications for Managers." Journal of Financial Economics 36 (October): 225-58.

Kato, Takao. 1997. "Chief Executive Compensation and Corporate Groups in Japan: New Evidence from Micro Data." International Journal of Industrial Organization 15 (July): 455 -67. 
Kato, Takao; Woochan Kim and Ju Ho Lee. 2004. "Executive Compensation, Firm Performance and Chaebols in Korea: Evidence from New Panel Data." Paper presented at the 2004 ASSA Meetings, San Diego, January 3-5 (revised in May 2004)

Kato, Takao and Katsuyuki Kubo. 2003. "Ceo Compensation and Firm Performance in Japan: Evidence from New Panel Data on Individual Ceo Pay." Working Paper No. 210, Center on Japanese Economy and Business, Columbia Business School (forthcoming in Journal of the Japanese and International Economies).

Kato, Takao and Cheryl Long. 2004. "Executive Compensation, Firm Performance, and State Ownership in China: Evidence from New Panel Data." William Davidson Institute Working Paper no. 690 (revised in November 2004), University of Michigan.

Ke, Bin; Kathy Petroni and Assem Safieddine. 1999. "Ownership Concentration and Sensitivity of Executive Pay to Accounting Performance Measures: Evidence from Publicly and Privately-Held Insurance Companies." Journal of Accounting and Economics 28 (December): 185-209.

Klapper, Leora F. and Inessa Love. 2002. "Corporate Governance, Investor Protection and Performance in Emerging Markets." forthcoming in Journal of Corporate Finance.

Kornai, Janos. 1992. The Socialist System: The Political Economy of Communism. Princeton: Princeton University Press.

Kubo, Katsuyuki, 2001, The Determinants of Executive Compensation in Japan and the UK: Agency Hypothesis or Joint Determination Hypothesis?, In Designing Financial Systems for East Asia and Japan, Forthcoming eds. M. Hanazaki, J. Fan and J. Teranishi, London: Routledge

Laffont, Jean-Jacques and Jean Tirole. 1993. A Theory of Incentives in Procurement and Regulation. Cambridge, MA: MIT Press.

Lardy, Nicholas R. 1998. China's Unfinished Economic Revolution. Washington, D.C.: Brookings Institution Press.

Lin, Cyril. 2000. "Corporatisation and Corporate Governance in China's Economic Transition." Department of Economics Series Ref: 020, Oxford University.

. 2001. "Corporatisation and Corporate Governance in China's Economic Transition." Economics of Planning 34 5-35.

Lin, Justin Yifu; Fang Cai and Zhou Li. 1998. "Competition, Policy Burdens, and State-Owned Enterprise Reform." American Economic Review 88 (May): 422-27.

Litwack, John M. 1991. "Legality and Market Reform in Soviet-Type Economies." Journal of Economic Perspectives 5 (Fall): 77-89.

Liu, Deqiang and Otsuka Keijiro. 2004. "A Comparison of Management Incentives, Abilities, and Efficiency between SOEs and TVEs: The Case of the Iron and Steel Industry in China." forthcoming in Economic Development and Cultural Change.

Megginson, William L. and Jeffry M. Netter. 2001. "From State to Market: A Survey of Empirical Studies on Privatization." Journal of Economic Literature 39 (June): 321-89.

Mok, H.M.K. and Y.V. Hui. 1998. "Underpricing and the Aftermarket Performance of IPOs in Shanghai, China." Pacific-Basin Finance Journal 6, 453-474.

Morck, Randall and Masao Nakamura. 1999. "Banks and Corporate Control in Japan." Journal of Finance 54 (February): 319-39.

Murphy, Kevin J., 1999, Executive Compensation, In Handbook of Labor Economics. Volume $3 b$ Amsterdam; New York and Oxford: Elsevier Science, North-Holland

Nam, Sang-Woo and Il Chong Nam. 2004. "Corporate Governance in Asia: Recent Evidence from Indonesia, Republic of Korea, Thailand and Malaysia." Unpublished manuscript, Asian Development Bank Institute.

Naughton, Barry. 1995. Growing out of the Plan: Chinese Economic Reform, 1978-1993. Cambridge University Press.

Perotti, Enrico C. 1995. "Credible Privatization." American Economic Review 85 (September): 847-59.

Rajan, Raghuram and Julie Wulf. 2004. "Are Perks Purely Managerial Excess?" NBER Working Papers no. 10494, National Bureau of Economic Research. 
Randoy, Trond and Jim Nielsen. 2002. "Company Performance, Corporate Governance, and Ceo Compensation in Norway and Sweden." Journal of Management and Governance 6 57-81.

Rosen, Sherwin. 1990. "Contracts and the Market for Executives." NBER Working Paper, no. 3542, National Bureau of Economic Research.

Schaefer, Scott. 1998. "The Dependence of Pay-Performance Sensitivity on the Size of the Firm." Review of Economics and Statistics 80 436-43.

Schipani, Cindy A. and Liu Junhai. 2001. "Corporate Governance in China: Then and Now." William Davidson Institute Working Paper no. 407, University of Michigan.

Schmidt, Klaus M. and Monika Schnitzer. 1993. "Privatization and Management Incentives in the Transition Period in Eastern Europe." Journal of Comparative Economics 17 (June): 264-87.

Shleifer, Andrei. 1998. "State Versus Private Ownership." Journal of Economic Perspectives 12 (Fall): 133-50.

Shleifer, Andrei and Robert W. Vishny. 1997. "A Survey of Corporate Governance." Journal of Finance 52 (June): 737-83.

Stiglitz, Joseph E., 1997, The Role of Government in Economic Development, in Annual World Bank Conference on Development Economics, 1996 (World Bank, Washington, D.C.)

Sun, Qian and Wilson H. S. Tong. 2003. "China Share Issue Privatization: The Extent of Its Success." Journal of Financial Economics 70 (November): 183-222.

Volpin, Paolo F. 2002. "Governance with Poor Investor Protection: Evidence from Top Executive Turnover in Italy." Journal of Financial Economics 64 (April): 61-90.

Wei, Zuobao; Feixue Xie and Shaorong Zhang. 2005. "Ownership Structure and Firm Value in China's Privatized Firms: 1991-2001." Journal of Financial and Quantitative Analysis 40 87-108.

Weitzman, Martin L. 1976. "The New Soviet Incentive Model." Bell Journal of Economics 7 (Spring): 251-57.

Wu, Jianlian (in Chinese). 2003. China Economic Reform (Zhongguo Jingji Gaige). Shanghai: Shanghai Yuandong Publishing.

Xiao, Fengtong. 2003. The Reform, Adjustment, and Development of China's State-Owned Enterprises. Beijing, China: Economic Science Publishing.

Xu, Peng. 1997. "Executive Salaries as Tournament Prizes and Executive Bonuses as Managerial Incentives in Japan." Journal of the Japanese and International Economies 11 (September): 31946.

Xu, X. and Y. Wang. 1997. "Ownership Structure, Corporate Governance, and Corporate Performance." Policy Research Working Paper no. 1794, The World Bank, Washington, DC.

Yang, Qixian, 1997, SOE Reforms and Institutional Renovations, In The Future Road of State Owned Enterprises. eds. F. Dong, Y. Li and Z. Han, Beijing, P.R. China: Economic Science Publishing

Yueh, Linda Y. 2004. "Wage Reform in China During the 1990s." forthcoming in Asian Economic Journal.

Zhang, Anming; Yimin Zhang and Ronald Zhao. 2003. "A Study of the R\&D Efficiency and Productivity of Chinese Firms." Journal of Comparative Economics 31 (September): 444-64. 
Table 1: The Level of Executive Compensation and Key Firm Characteristics of China's Listed Firms, 1998-2002.

\begin{tabular}{|c|c|c|c|}
\hline Variable & Mean & $\begin{array}{l}\text { Standard } \\
\text { Deviation }\end{array}$ & Observations \\
\hline \multicolumn{4}{|l|}{ Executive compensation } \\
\hline $\begin{array}{l}\text { TOP THREE EXECUTIVE AVERAGE PAY (total annual } \\
\text { salary for the highest-paid three executives divided by three) }\end{array}$ & $97,474.220$ & $101,249.100$ & 1,917 \\
\hline \multicolumn{4}{|l|}{ Key firm characteristics } \\
\hline Number of employees & 3,336.687 & $14,462.350$ & 1,901 \\
\hline Size of board of directors & 9.719 & 2.466 & 1,917 \\
\hline Size of board of supervisors & 4.321 & 1.386 & 1,917 \\
\hline Number of directors, supervisors, and executives & & & \\
\hline included in TOTAL EXECUTIVE PAY & 11.192 & 5.463 & 1,917 \\
\hline Sales (in 1,000 RMB) & $1.38 \mathrm{E}+06$ & $9.45 E+06$ & 1,917 \\
\hline VALUE (shareholder value in 1,000 RMB) & $1.70 \mathrm{E}+06$ & $4.16 \mathrm{E}+06$ & 1,917 \\
\hline R (stock return) & -0.138 & 0.248 & 1,917 \\
\hline Asset (in 1,000 RMB) & 2220 & & 1,917 \\
\hline ROA (pre-tax profit/assets) & 0.013 & 0.324 & 1,917 \\
\hline $\begin{array}{l}\text { NEGPROF }=1 \text { if the firm's pre-tax profit is negative, } \\
0 \text { otherwise }\end{array}$ & 0.123 & 0.329 & 1,917 \\
\hline $\begin{array}{l}\text { GVTSHARE (percentage of company shares owned } \\
\text { by the state) }\end{array}$ & 59.545 & 12.532 & 1,910 \\
\hline
\end{tabular}

Sources: Accounting and financial data are from the China Stock Market and Accounting Research Database (CSMAR) developed by Shenzhen GTA Information Technology Company. Data on executive compensation are from the database developed by Sinofin Information Services.

Note: The data are based on a pooled cross-sectional time series dataset on 923 listed firms over the sample period of 1998 to 2002. All compensation measures, VALUE, and Sales are adjusted for inflation using CPI (1995=100). VALUE and Sales are in thousands of 1995 RMB, while all compensation measures are in $1995 \mathrm{RMB}$. 


\begin{tabular}{|c|c|c|c|}
\hline Variable & Mean & $\begin{array}{l}\text { Standard } \\
\text { Deviation }\end{array}$ & Observations \\
\hline \multicolumn{4}{|l|}{ Executive compensation } \\
\hline$\Delta \mathrm{Y}=\Delta($ TOP THREE EXECUTIVE AVERAGE PAY) & $14,292.720$ & $215,754.600$ & 943 \\
\hline$\Delta \ln Y$ & 0.248 & 0.549 & 941 \\
\hline \multicolumn{4}{|l|}{ Stock performance } \\
\hline$\Delta \mathrm{V}=\Delta(\mathrm{VALUE})$ & $-2.260 \mathrm{E}+05$ & $6.130 \mathrm{E}+05$ & 1,033 \\
\hline $\mathrm{R}$ & -0.118 & 0.274 & 1,033 \\
\hline $\ln (1+R)$ & -0.161 & 0.251 & 1,033 \\
\hline \multicolumn{4}{|l|}{ Alternative firm performance measures } \\
\hline $\mathrm{S}=$ rate of growth of sales from $\mathrm{t}-1$ to $\mathrm{t}$ & 0.183 & 0.426 & 1,017 \\
\hline$\Delta \mathrm{P}=$ change in ROA from year $\mathrm{t}-1$ to year $\mathrm{t}$ & -0.026 & 0.432 & 1,033 \\
\hline $\mathrm{N}=\mathrm{NEGPROF}$ & 0.135 & 0.341 & 1,033 \\
\hline \multicolumn{4}{|l|}{ Ownership Structure } \\
\hline $\mathrm{G}=\mathrm{GVTSHARE}$ & 59.408 & 12.615 & 1,030 \\
\hline \multicolumn{4}{|l|}{ Other firm characteristics } \\
\hline $\begin{array}{l}\mathrm{A}=\text { asset } \\
\mathrm{I} 1=1 \text { if the firm is in the primary sector (agriculture and }\end{array}$ & 0.000222 & 0.00111 & 1,030 \\
\hline mining) & 0.042 & & 1,030 \\
\hline $\begin{array}{l}\mathrm{I} 2=1 \text { if the firm is in the manufacturing sector } \\
\mathrm{I} 3=1 \text { if the firm is in the public utility sector (public }\end{array}$ & 0.622 & & 1,030 \\
\hline $\begin{array}{l}\text { transportation and communications) } \\
\text { I } 4=1 \text { if the firm is in the commercial sector (retail and }\end{array}$ & 0.123 & & 1,030 \\
\hline wholesale trade and real estate) & 0.146 & & 1,030 \\
\hline $\mathrm{I} 5=1$ if the firm is in all other sectors & 0.067 & & 1,030 \\
\hline
\end{tabular}

Sources: Accounting and financial data are from the China Stock Market and Accounting Research Database (CSMAR) developed by Shenzhen GTA Information Technology Company. Data on executive compensation are from the database developed by Sinofin Information Services.

Note: The data are based on a pooled cross-sectional time series dataset on 827 listed firms. All compensation measures, VALUE, and Sales are adjusted for inflation using CPI (1995=100). VALUE and Sales are in thousands of 1995 RMB, while all compensation measures are in 1995 RMB. 
Table 3: Executive Pay-Performance Sensitivities and Elasticities in China's Listed Firms

\begin{tabular}{|c|c|c|c|c|}
\hline \multirow{3}{*}{$\begin{array}{l}\text { Independent } \\
\text { Variable }\end{array}$} & (i) & (ii) & (iii) & (iv) \\
\hline & \multicolumn{4}{|c|}{ Dependent Variable= } \\
\hline & $\Delta \mathrm{Y}$ & $\Delta \ln Y$ & $\Delta \mathrm{Y}$ & $\Delta \ln Y$ \\
\hline 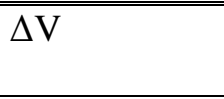 & $\begin{array}{l}0.045 \\
(3.79)^{* *}\end{array}$ & & $\begin{array}{l}0.054 \\
(4.18)^{* *}\end{array}$ & \\
\hline $\ln (1+R)$ & & $\begin{array}{l}0.174 \\
(2.28)^{*}\end{array}$ & & $\begin{array}{l}0.363 \\
(3.67)^{* *}\end{array}$ \\
\hline $\begin{array}{l}\text { Year dummy } \\
\text { variables }\end{array}$ & No & No & Yes & Yes \\
\hline Observations & 940 & 938 & 940 & 938 \\
\hline R-squared & 0.015 & 0.006 & 0.019 & 0.020 \\
\hline
\end{tabular}

Source and Variable Definitions: See Tables 1 and 2.

Note: The data are based on a pooled cross-sectional time series dataset on 827 listed firms. All models include constant term. All compensation measures are in 1995 RMB. There are four year dummy variables: T1999=1 if the observation is for year 1999, and T2000, T2001 and T2002 are defined likewise, and T1999 is omitted as a reference year. Absolute value of $t$ statistics in parentheses.

+ significant at $10 \% ; *$ significant at $5 \%$; ** significant at $1 \%$ 
Table 4 Semi-Elasticities of Executive Pay with respect to Alternative Performance Measures in China's Listed Firms:

\begin{tabular}{|c|c|c|c|c|c|}
\hline \multirow{2}{*}{$\begin{array}{l}\text { Independent } \\
\text { Variable } \\
\end{array}$} & (i) & (ii) & (iii) & (iv) & (v) \\
\hline & \multicolumn{5}{|c|}{ Dependent variable $=\Delta \ln Y$} \\
\hline $\mathrm{R}$ & $\begin{array}{l}0.343 \\
(3.40)^{* *}\end{array}$ & & & & $\begin{array}{l}0.290 \\
(2.79)^{* *}\end{array}$ \\
\hline $\mathrm{S}$ & & $\begin{array}{l}0.179 \\
(4.07)^{* *}\end{array}$ & & & $\begin{array}{l}0.137 \\
(2.98)^{* *}\end{array}$ \\
\hline$\triangle \mathrm{P}$ & & & $\begin{array}{l}0.057 \\
(1.44)\end{array}$ & & $\begin{array}{l}0.016 \\
(0.40) \\
\end{array}$ \\
\hline $\mathrm{N}$ & & & & $\begin{array}{l}-0.176 \\
(3.32)^{* *} \\
\end{array}$ & $\begin{array}{l}-0.103 \\
(1.83)+ \\
\end{array}$ \\
\hline Observations & 938 & 927 & 938 & 938 & 927 \\
\hline R-squared & 0.018 & 0.024 & 0.009 & 0.018 & 0.037 \\
\hline
\end{tabular}

Source and Variable Definitions: See Tables 1 and 2.

Note: The data are based on a pooled cross-sectional time series dataset on 827 listed firms. All models include constant term and year dummy variables (There are four year dummy variables: T1999=1 if the observation is for year 1999, and T2000, T2001 and T2002 are defined likewise, and T1999 is omitted as a reference year). All compensation measures are in 1995 RMB.

Absolute value of $t$ statistics in parentheses.

+ significant at $10 \% ; *$ significant at $5 \%$; ** significant at $1 \%$ 
Table 5 Executive Pay-Performance Sensitivities and Elasticities, and State Ownership in China's Listed Firms

\begin{tabular}{|c|c|c|c|c|c|c|c|c|}
\hline \multirow{4}{*}{$\begin{array}{l}\text { Independent } \\
\text { variable }\end{array}$} & (i) & (ii) & (iii) & (iv) & (v) & (vi) & (vii) & (viii) \\
\hline & \multirow{2}{*}{\multicolumn{4}{|c|}{ Dependent variable= }} & \multicolumn{2}{|c|}{ Using lagged G } & \multicolumn{2}{|c|}{$\begin{array}{l}\text { Considering only firms in } \\
\text { targeted industries with } \\
\text { guaranteed access to state capital }\end{array}$} \\
\hline & & & & & \multicolumn{4}{|c|}{ Dependent variable= } \\
\hline & $\Delta \mathrm{Y}$ & $\Delta \ln Y$ & $\Delta \mathrm{Y}$ & $\Delta \ln Y$ & $\Delta \mathrm{Y}$ & $\Delta \ln \mathrm{Y}$ & $\Delta \mathrm{Y}$ & $\Delta \ln Y$ \\
\hline$\Delta \mathrm{V}$ & $\begin{array}{l}0.253 \\
(4.56)^{* *}\end{array}$ & & $\begin{array}{l}0.190 \\
(1.71)+\end{array}$ & & $\begin{array}{l}0.183 \\
(1.66)+\end{array}$ & & $\begin{array}{l}0.086 \\
(1.73)+\end{array}$ & \\
\hline$\Delta \mathrm{V}^{*} \mathrm{G}$ & $\begin{array}{l}-0.003 \\
(3.69)^{* *}\end{array}$ & & $\begin{array}{l}-0.003 \\
(2.91)^{* *}\end{array}$ & & $\begin{array}{l}-0.003 \\
(2.92)^{* *}\end{array}$ & & $\begin{array}{l}-0.002 \\
(1.77)+\end{array}$ & \\
\hline $\ln (1+R)$ & & $\begin{array}{l}1.235 \\
(3.36)^{* *}\end{array}$ & & $\begin{array}{l}1.429 \\
(2.77) * *\end{array}$ & & $\begin{array}{l}1.445 \\
(2.80)^{* *}\end{array}$ & & $\begin{array}{l}2.256 \\
(2.51)^{* *}\end{array}$ \\
\hline $\ln (1+R) * G$ & & $\begin{array}{l}-0.015 \\
(2.46)^{*}\end{array}$ & & $\begin{array}{l}-0.016 \\
(2.59) * *\end{array}$ & & $\begin{array}{l}-0.016 \\
(2.64)^{* *}\end{array}$ & & $\begin{array}{l}-0.044 \\
(2.80)^{* *}\end{array}$ \\
\hline G & $\begin{array}{l}-698.870 \\
(1.15)\end{array}$ & $\begin{array}{l}-0.003 \\
(1.84)+\end{array}$ & $\begin{array}{l}-608.934 \\
(0.99)\end{array}$ & $\begin{array}{l}-0.004 \\
(2.15)^{*}\end{array}$ & $\begin{array}{l}-483.950 \\
(0.81)\end{array}$ & $\begin{array}{l}-0.004 \\
(2.18)^{*}\end{array}$ & $\begin{array}{l}-702.734 \\
(1.50)\end{array}$ & $\begin{array}{l}-0.009 \\
(2.80)^{* *}\end{array}$ \\
\hline A & & & $\begin{array}{l}4.742 \mathrm{E}-04 \\
(0.21)\end{array}$ & $\begin{array}{l}4.450 \mathrm{E}-09 \\
(1.23)\end{array}$ & $\begin{array}{l}3.620 \mathrm{E}-04 \\
(0.16)\end{array}$ & $\begin{array}{l}\text { 4.440E-09 } \\
(1.23)\end{array}$ & $\begin{array}{l}0.002 \\
(1.40)\end{array}$ & $\begin{array}{l}7.450 \mathrm{E}-10 \\
(0.07)\end{array}$ \\
\hline$\Delta \mathrm{V}^{*} \mathrm{~A}$ & & & $\begin{array}{l}2.990 \mathrm{E}-10 \\
(0.98)\end{array}$ & & $\begin{array}{l}2.850 \mathrm{E}-10 \\
(0.94)\end{array}$ & & $\begin{array}{l}2.930 \mathrm{E}-10 \\
(1.72)+\end{array}$ & \\
\hline $\ln (1+\mathrm{R}) * A$ & & & & $\begin{array}{l}\text { 5.060E-08 } \\
(1.48)\end{array}$ & & $\begin{array}{l}\text { 5.060E-08 } \\
(1.48)\end{array}$ & & $\begin{array}{l}\text { 6.860E-09 } \\
(0.06)\end{array}$ \\
\hline Sector effect & No & No & Yes & Yes & Yes & Yes & Yes & Yes \\
\hline Observations & 940 & 938 & 940 & 938 & 940 & 938 & 129 & 129 \\
\hline R-squared & 0.033 & 0.027 & 0.104 & 0.042 & 0.104 & 0.042 & 0.092 & 0.105 \\
\hline
\end{tabular}

Source and Variable Definitions: See Table 1.

Note: The data are based on a pooled cross-sectional time series dataset on 827 listed firms. All models include constant term and year dummy variables (There are four year dummy variables: T1999=1 if the observation is for year 1999, and T2000, T2001 and T2002 are defined likewise, and T1999 is omitted as a reference year). VALUE is in thousands of $1995 \mathrm{RMB}$, while all compensation measures are in 1995 RMB. Absolute value of $t$ statistics in parentheses. The sector effects are captured by adding four sector dummy variables (primary, manufacturing, public utility, and commercial (other sector category excluded as a reference) and four interaction terms involving each sector dummy variable and firm performance. For Specifications (vii) and (viii), primary sector dummy variable is omitted since no primary sector firm is in targeted industries.

+ significant at $10 \%$; * significant at $5 \%$; ** significant at $1 \%$ 
Figure 1 Box-Whisker Plot of executive pay growth and stock return

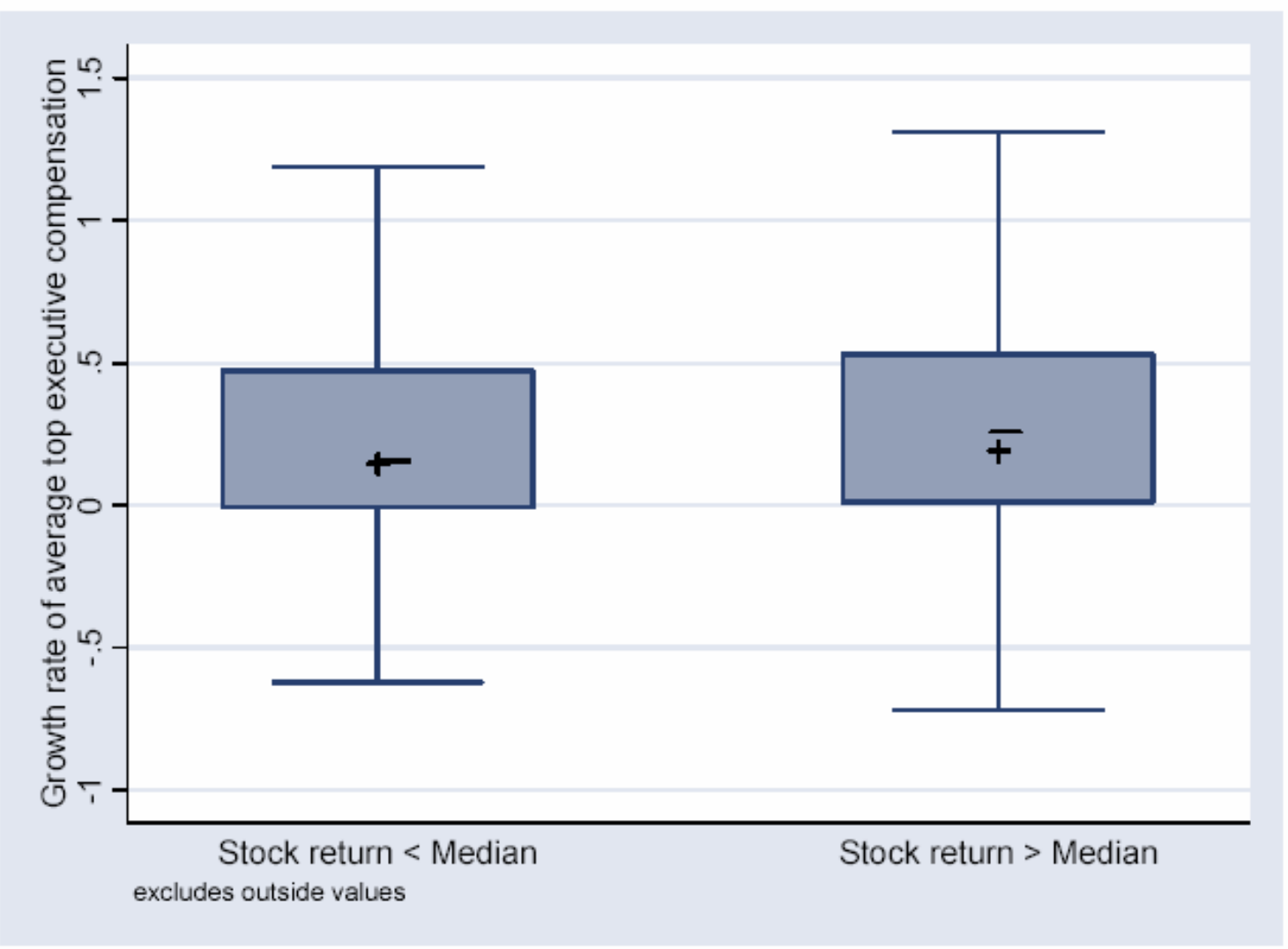

Note: The graphs from left to right correspond to firms with below medium stock return and firms with above medium stock return. The upper and lower ends of the whiskers indicate the UAV (upper adjacent value) and the LAV (lower adjacent value), the upper and lower boundaries of the box indicate the upper quartile and the lower quartile, “+” indicates the medium, and "-" indicates the mean value of the growth rate of average top executive compensation. 
Figure 2 Box-Whisker Plot of executive pay growth and sales growth

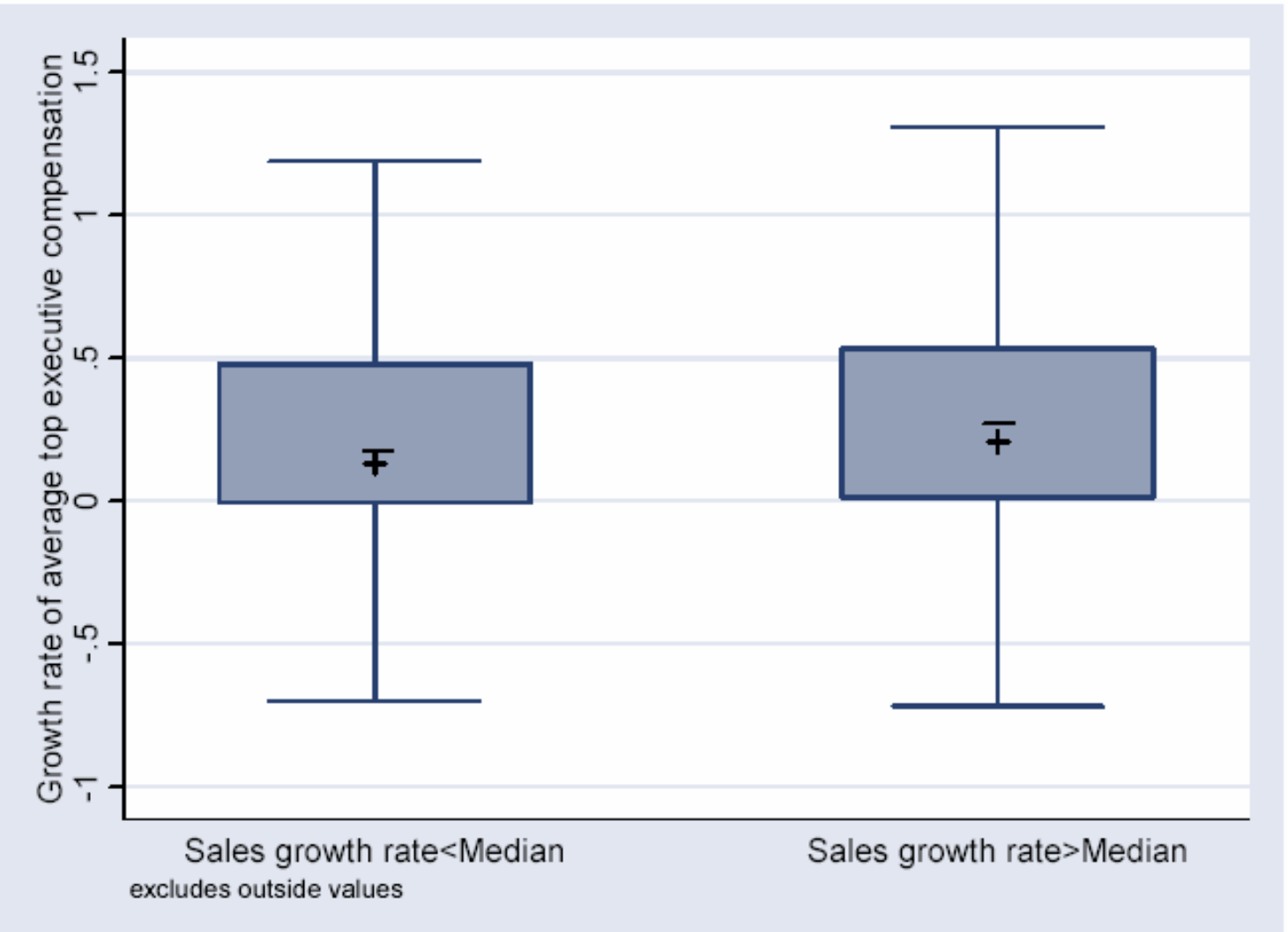

Note: The graphs from left to right correspond to firms with below medium sales growth rate and firms with above medium sales growth rate. The upper and lower ends of the whiskers indicate the UAV (upper adjacent value) and the LAV (lower adjacent value), the upper and lower boundaries of the box indicate the upper quartile and the lower quartile, "+" indicates the medium, and "-” indicates the mean value of the growth rate of average top executive compensation. 
Figure 3 Box-Whisker Plot of executive pay growth and ROA growth

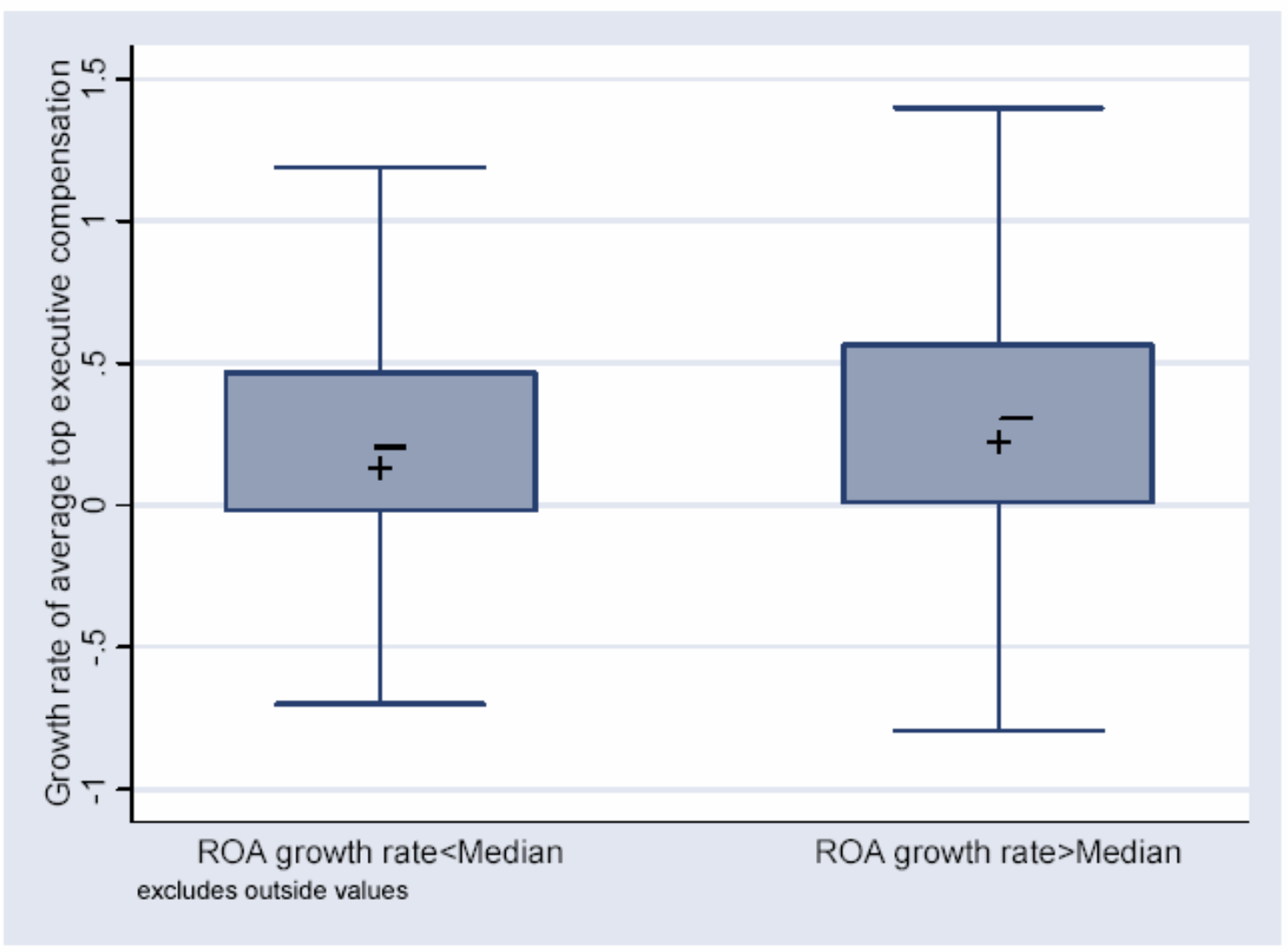

Note: The graphs from left to right correspond to firms with below medium ROA growth rate and firms with above medium ROA growth rate. The upper and lower ends of the whiskers indicate the UAV (upper adjacent value) and the LAV (lower adjacent value), the upper and lower boundaries of the box indicate the upper quartile and the lower quartile, “+” indicates the medium, and "-" indicates the mean value of the growth rate of average top executive compensation. 
Figure 4 Box-Whisker Plot of executive pay growth and negative profit

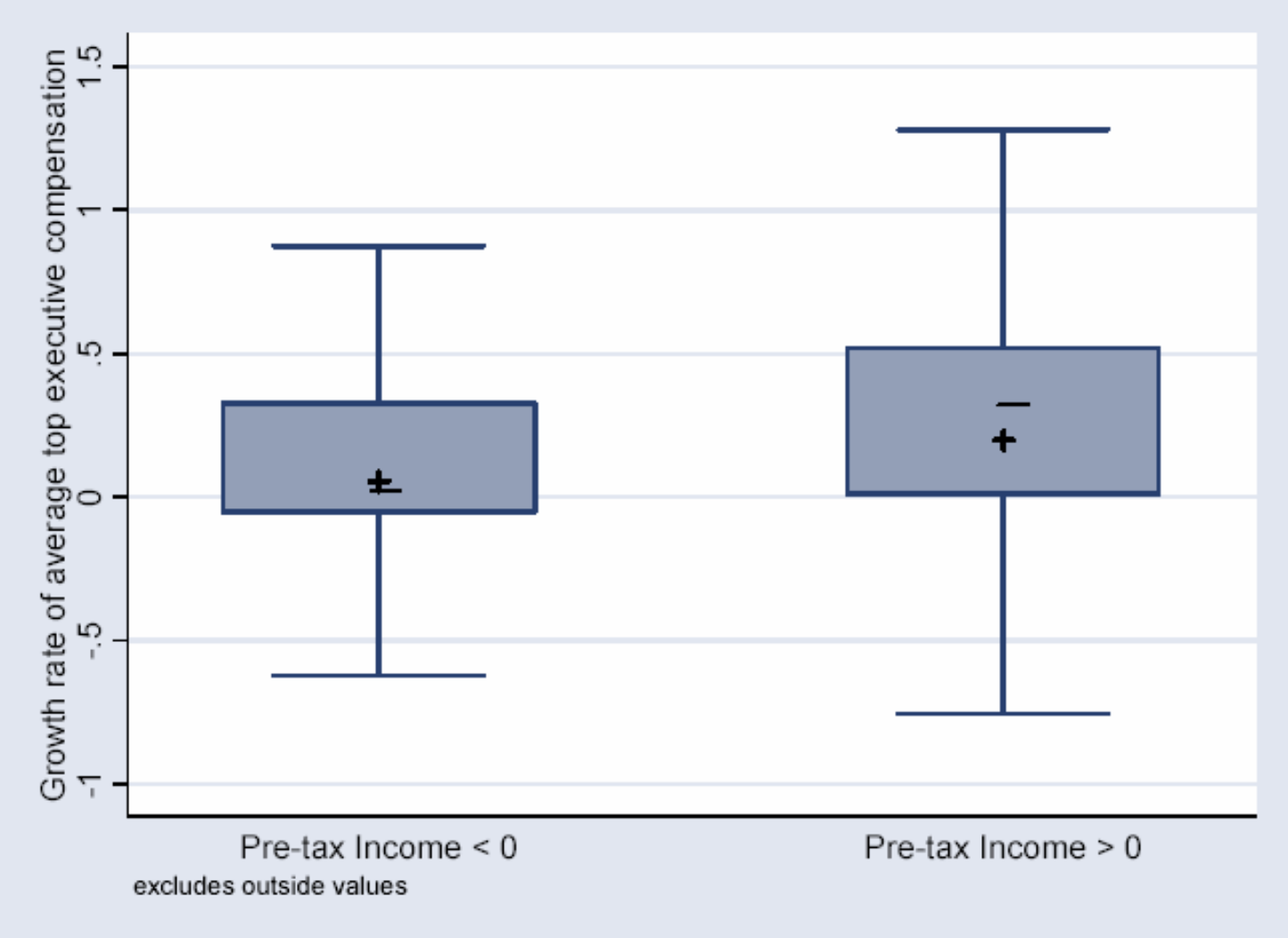

Note: The graphs from left to right correspond to firms with negative pre-tax income and firms with positive pre-tax income. The upper and lower ends of the whiskers indicate the UAV (upper adjacent value) and the LAV (lower adjacent value), the upper and lower boundaries of the box indicate the upper quartile and the lower quartile, “+” indicates the medium, and “-” indicates the mean value of the growth rate of average top executive compensation. 